IZA DP No. 7529

The Effect of Sexual Activity on Wages

Nick Drydakis

July 2013 


\title{
The Effect of Sexual Activity on Wages
}

\author{
Nick Drydakis \\ Anglia Ruskin University, \\ IZA and Scientific Centre for the Study of Discrimination, Athens
}
Discussion Paper No. 7529
July 2013

\author{
IZA \\ P.O. Box 7240 \\ 53072 Bonn \\ Germany \\ Phone: +49-228-3894-0 \\ Fax: +49-228-3894-180 \\ E-mail: iza@iza.org
}

\begin{abstract}
Any opinions expressed here are those of the author(s) and not those of IZA. Research published in this series may include views on policy, but the institute itself takes no institutional policy positions. The IZA research network is committed to the IZA Guiding Principles of Research Integrity.

The Institute for the Study of Labor (IZA) in Bonn is a local and virtual international research center and a place of communication between science, politics and business. IZA is an independent nonprofit organization supported by Deutsche Post Foundation. The center is associated with the University of Bonn and offers a stimulating research environment through its international network, workshops and conferences, data service, project support, research visits and doctoral program. IZA engages in (i) original and internationally competitive research in all fields of labor economics, (ii) development of policy concepts, and (iii) dissemination of research results and concepts to the interested public.
\end{abstract}

IZA Discussion Papers often represent preliminary work and are circulated to encourage discussion. Citation of such a paper should account for its provisional character. A revised version may be available directly from the author. 


\section{ABSTRACT \\ The Effect of Sexual Activity on Wages}

The purpose of this study is to estimate whether sexual activity is associated with wages, and also to estimate potential interactions between individuals' characteristics, wages and sexual activity. The central hypothesis behind this research is that sexual activity, like health indicators and mental well-being, may be thought of as part of an individual's set of productive traits that affect wages. Using two stage estimations we examine the relationship between adult sexual activity and wages. We estimate that there is a monotonic relationship between the frequency of sexual activity and wage returns, whilst the returns to sexual activity are higher for those between 26 and 50 years of age. In addition, heterosexuals' sexual activity does not seem to provide higher or lower wage returns than that of homosexuals, but wages are higher for those health-impaired employees who are sexually active. Over-identification tests, robustness checks, falsification tests, as well as, decomposition analysis and sample selection modelling enhance the study's strength. Contemporary social analysis suggests that health, cognitive and non-cognitive skills and personality are important factors that affect the wage level. Sexual activity may also be of interest to social scientists, since sexual activity is considered to be a barometer for health, quality of life, well-being and happiness. The paper adds to the literature on the importance of unobserved characteristics in determining labour market outcomes.

JEL Classification: J10, J30, J24

Keywords: sexual activity, wages, endogeneity, sample selection, decompositions

Corresponding author:

Nick Drydakis

Lord Ashcroft International Business School

Anglia Ruskin University

East Road

Cambridge, CB1 1PT

United Kingdom

E-mail: nick.drydakis@anglia.ac.uk 


\section{Introduction and conceptual considerations}

The purpose of this study is to examine whether sexual activity is associated with wages. The literature exchange perspective provides a lens through which we can examine this hypothesis. The central hypothesis behind this research is that sexual activity, alike health indicators and mental well-being, may be thought of as part of an individual's set of productive traits that affect wages. The vast medical and psychological literature concludes that sexual activity is associated with good health and improved physical and mental capacities, psychological well-being, and dietary habits. Scholarly studies suggest that there is a positive relationship between sexual intercourse, well-being and longevity (Palmore, 1982; Onder et al., 2003; Planned Parenthood Federation of America, 2003; Lindau and Gavrilova, 2010). In addition, several studies suggest that mental health, personal happiness, satisfaction, self-esteem, conscientiousness, cognitive functioning and reasoning ability are positively related to the frequency of sexual activity, and that sexual activity is negatively associated with the risks and incidences of depression and stress (Shulman and Horne, 2003; Lykins et al., 2006; Lindau et al., 2007; Witting et al., 2008; Brody, 2010; Hooghe, 2011; Vrangalova and Savin-Williams, 2011). Furthermore, there are suggestions that people with active sex lives tend to exercise more frequently, have more strength and endurance, and have better dietary habits than those who are less sexually active (Ellison, 2000; Planned Parenthood Federation of America, 2003).

Sexual activity allows distinct predictions to be made regarding labour market success, since economists consider health status, mental health, and dietary 
habits/obesity to be crucial variables that influence employees' wages ${ }^{1}$. Economic studies indicate that individuals with health problems earn less due to limited productivity, unobserved preferences and/or discrimination (Acemoglu and Angrist, 2001; Campolieti, 2002; Jones et al., 2006). For the same reasons, the research suggests that obese people receive lower wages (Cawley, 2004; Norton et al., 2008; Han et al., 2009). In addition, economists increasingly view mental health, behaviour and personality traits as non-cognitive skills that can have important consequences for the economic decisions that individuals make and the outcomes they achieve. Indeed, adverse mental health symptoms (depression, anxiety, and neuroticism) have been proven to negatively influence earnings (Mueller and Plug, 2006; Heineck and Anger, 2010).

The bulk of the economic literature on the determination of wages has, for a long time, primarily concentrated on traditional human capital variables (skills), such as education and actual work experience (Mincer, 1958; Becker, 1975). Human capital is one of the most important factors that affects labour productivity. More recently, studies that focus on cognition and earnings find that returns to cognitive ability, measured by standardised IQ test scores, are positive and significant and affect an employee's wages (Mueller and Plug, 2006). A growing literature also incorporates non-cognitive traits, mainly behaviour and personality characteristics, arguing that differences in these traits may result in differences in job performance that may then lead to better promotion

\footnotetext{
${ }^{1}$ Consider however that wage determination remains mainly a labour market outcome (strictly associated with macroeconomic fundamentals, market structure, trade unions etc.).
} 
prospects or increased earnings potential (Cawley, et. al. 2001; Heineck and Anger; 2010).

The above-noted conceptual considerations and findings from previous research on the benefits of sexual activity and the knowledge of the determinants of labour market outcomes enable us to set expectations for the analyses in the present study. In line with prior research, since good health, mental health, and well-being are closely related to the economist's notion of productive output, and these characteristic are correlated with sexual activity, we may expect/hypothesise that sexual activity is also a well-being indicator related to higher wages.

The reasoning just described, and the consideration of all these parameters, suggest that sexual activity can be associated with many economic measurements and phenomena, and it is thus surprising that only two economics-based studies have been carried out. In an influential study using US data, Blanchflower and Oswald (2004) explore the association between income, sex and happiness and estimate that "sexual activity enters strongly positive in happiness equation”, that is, the more sex a person has, the happier the person is. The authors also predict that increased income does not buy greater happiness, nor does it translate to more sex and sexual partners. The authors emphasise, however, the possibility of endogeneity problems, and the lack of instrumental variables drives the authors to provide single-equation estimates. In addition, Loureiro et al. (2009) show positive correlations between sexual frequency and wages for Brazilian employees. However, they did not discuss endogeneity problems.

The studies of Blanchflower and Oswald (2004) and Loureiro et al. (2009) provide incentives for a conceptual consideration of the link between sexual activity and 
wages, based on economic theory. Unfortunately, however, it is unclear whether these associations represent a causal relationship or can be explained by unmeasured heterogeneity. Indeed, if unobserved factors are correlated with both sexual activity and wages then the relationship between these variables is potentially spurious. In the current paper, using the 2008 Greek Behavioural Study of females and males 18 through 65 years of age, this study contributes to the literature by using two-stage estimations to examine the relationship between adult sexual activity and wages, after considering various characteristics. In addition, we are interested in documenting potential interactions between individuals' characteristics and wages and sexual activity. A range of over-identification tests, robustness checks, and falsification tests bolster the case for a causal interpretation of the relation under consideration. We will conclude that there is a monotonic relationship between the frequency of sexual activity and wage returns. Moreover, the returns to sexual activity are higher for those between 26 and 50 years of age. In addition, heterosexuals' sexual activity does not seem to provide higher or lower wage returns than that of homosexuals. Whilst, wages are higher for those health-impaired employees who are sexually active. Finally, decomposition analysis and sample selection modelling will enhance study’s strength.

The rest of the paper is organised as follows: Section 2 describes the dataset, analyses the variables used in this study, and presents the descriptive statistics. Section 3 introduces the empirical model. Section 4 analyses the two-stage regression outcomes. The last section concludes the study. 


\section{Data set and descriptive statistics}

\section{2.a Definition of variables}

The data were gathered from January 2008 through December 2008 in the Greek Behavioural Study (GBS), conducted by the University of Piraeus, the University of Central Greece, and the Panteion University of Social and Political Sciences. The 2008 GBS is one component of the Multi-country Study of the Scientific Centre for the Study of Discrimination (SCSD), which has collected information on Greek citizens. The 2008 GBS consisted of random telephone-based surveys to approximately 7,500 households. Individuals in each household were randomly selected to provide information on a variety of demographic characteristics. Respondents in the GBS were asked how many times they engaged in sexual activity (SA). This question was the same as the US General Social Survey (GSS) question. Although this was a sensitive area about which to question individuals, there is a body of knowledge on how it can best be done (Michael et al., 1994; Gribble et al., 1999), and we conducted the study in keeping with this knowledge. Respondents were asked to choose among seven options: no sex (code 0); sex once or twice a year (code 1); sex once a month (code 2); sex two to three times a month (code 3); sex weekly (code 4); sex two to three times a week (code 5); and sex more than four times a week (code 6).

Respondents were asked to fill in two separate questions: whether they were employed (EMPL), and whether they were participants (LAFOR) in the labour force (i.e employed and unemployed). Wages were measured as a continuous variable. The GBS constructed an hourly wage measure by dividing the last month's wages by selfreported working hours per month. Surveyors asked, "What is your best estimate of your wage last month before taxes and other deductions?”. In addition, the variable 
EXPER measured the individual's years of work experience. To allow for the possibility of a non-linear relationship between wage and work experience, the square of age (EXPERDQ) was included in the regression. Two dummy variables for occupational categories were included in the analysis. The variable WHITE was set to 1 if the individual's occupation was considered white-collar and 0 otherwise. The variable PUBL was set to 1 if the worker was employed in the public sector and 0 otherwise.

In addition, the variable AGE measured the individual's age in years. For reasons discussed above, we also included the square of age (AGESQ) was included in the regression. To account for the possibility that the influence of sexual activity may differ by gender (men vs. women), a dummy variable for gender is included (GEN). The variable MARR was set to 1 if the respondent was married and 0 otherwise. Moreover, the GBS included a direct question about an individual's sexual orientation (see, Carpenter, 2005). To investigate sexual orientation, employees were asked: “The next question is about sexual orientation: Do you consider yourself to be: (1) Heterosexual? (2) Homosexual?”. In addition, the variable IMM was set to 1 if the individual was an immigrant (non-Greek) and 0 otherwise. The variable UNIV was set to 1 if the respondent had a university or technical-school diploma and 0 otherwise.

To be comparable to previous research, we defined disability status (DS) using the self-reported response to a question regarding whether an individual is limited in a kind or amount of work, has a mobility limitation, or has a personal care limitation (see, Baldwin and Johnson, 2000). Additional health indicators are defined separately for whether the respondent reported that she/he takes daily medications (DM), and she/he has been diagnosed with the following illnesses: diabetes (DIA); heart disease (HEA); arthritis (ART); cancer (CAN); and psychiatric/psychological symptoms (PSY). 
To deal with unobserved heterogeneity the Big Five Personality Traits index (Digman, 1990; McCrae and John, 1992) was employed. The Big Five Personality Traits measures individuals’ personality traits, such as: extraversion, agreeableness, conscientiousness, emotional stability, and openness. It is easy to imagine that difficultto-measure factors at individuals' personality (i.e. extraversion, openness) could influence both sexual activity and wages. For example if one is sociable, or shy or irritable may this pattern influence her/his sexual activity and wage (Digman, 1990; McCrae and John, 1992; Heineck and Anger 2010). The Big Five Personality Traits index controls various critical heterogeneities such as social recognition, commitment, popularity, energy level, self-esteem, physical attractiveness based on 40 behaviour criteria (Paunonen and Ashton, 2001).

Two additional variables were considered to address endogeneity (see section 3). The variable G measured whether the individual believes in a God, and the variable RS measured an individual's attendance of religious services. Whilst, three variables were considered for the falsification tests (see section 3). The variable WCS measured whether the individual is working in the capital city (Athens), the variable WOT measured whether the individual is working over-time, and the variable WPT measured whether the individual is working part-time. Finally, to deal with sample selection bias (see section 4.e) three additional variables were considered. The variable NINC measured the non-labour income, and the variables MUNI, FUNI measured highest education attainment (i.e. university or technical-school diploma) of the respondent mother and father. For convenience, variable definitions are summarised in the Appendix A. 


\subsection{Descriptive statistics}

Table 1 shows the descriptive statistics, stratified by gender, and this section offers a brief discussion. The sample consists of 7,500 respondents, however 1,183 respondents with missing information were dropped from the analyses (i.e. 15.7\%). What is of interest, however, is that the mean and standard deviation are the same for (i) those individuals who did not answer the sexual activity question (i.e $6.3 \%$ or 479 cases) and (ii) those individuals who answered the sexual activity question (i.e. 93.7\% or 7,021 cases). Chi-squared tests were employed, and none of the attempts concurred with the null hypothesis of a significant difference between groups (i) and (ii). Tables are available on request. A plausible explanation for this issue is that individuals might have felt bothered by the sexual activity question and declined to provide an answer, regardless of their demographic characteristics. However, difficult-to-measure patterns, such as family background characteristics, could be correlated with the decision to respond to the sexual activity question. Thus, it is not possible to exclude the presence of unobservable individual characteristics affecting the probability of (not) answering.

\section{[Table 1]}

As shown in Panel I, the measurement suggests that adult individuals approximately have weekly sex. The psychological and medical literature reviewed in the introductory section addresses this pattern (Ellison, 2000; Lykins et al., 2006; Hooghe, 2011). Sex activity shows a great variability in responses, which accredits why the measure is scientifically correct. Whilst, the reliability of the scale is considered to be satisfactory (Sex activity Cronbach's $\alpha=0.86$ ). Note also that, as with other variables (e.g., age, education), measurement errors in this sexual activity data are likely. One bias might stem from people who may wish to represent themselves to the 
survey interviewer as enjoying more sex than they do. However, another might stem from modesty or a wish to conceal extra-marital affairs. In this paper, as in most other studies, we take the numbers at face value and study the implied patterns in Greek society.

To continue with, the average age is 34.3 years, $47.4 \%$ of the subjects are men, and $5.5 \%$ are gay men/lesbian women. Moreover, the results indicate that $58.3 \%$ are married and $15.4 \%$ are immigrants, and $7.7 \%$ have health-limitations. Regarding education levels, $47.9 \%$ have a university or technical school degree, $93.1 \%$ are labour force participants, and $78.1 \%$ are employed. In addition, $39.1 \%$ are white collar employees, and 52.1\% are public employees. Moreover, individuals have 13.2 years of work experience and the hourly wage rate is 7.9 Euros. In Panels II and III, we offer descriptive statistics by gender. The outcomes are as expected for the Greek case. Notably, given the absence of census data, it is virtually impossible to test whether this sample is truly representative. However, this issue has been addressed by comparing the 2008 Greek Behavioural Study's descriptive statistics with those of the most recent Greek Household Budget Survey from 2005. A comparison of the two data sets reveals similar average ages for the respondents, as well as gender composition, and proportion of immigrants. This comparison suggests that the 2008 Greek Behavioural Study is, to a large extent, representative of individuals in Greece.

In this stage, we investigate also the inter-correlation matrix which will show whether sexual activity, as well as, wages are correlated with the variables used in this study. In Appendix B, we present a sub-correlation matrix (31x2). The whole intercorrelation matrix (31x31) is available on request. The outcomes suggest that there is positive and statistically significant correlation between sexual activity and wages, 
males, married people, and those people characterized by extraversion traits. In addition, there is a negative and statistically significant correlation between sexual activity and migrants, disability, daily medication, health indicators (diabetes, heart diseases, arthritis, cancer, psychiatric/psychological symptoms), believe in God, and religious services attendance. On the other hand, there is a positive and statistically significant correlation between wages and age, male employees, married people, those having upper education, actual working experience, white collar jobs, public jobs, working in the capital city, working over-time and extraversion traits. Whilst, there is a negative and statistically significant correlation between wages and immigrant people, homosexuals, disability status, daily medication, health indicators and part-time work. An endless interpretation analysis of each correlation's coefficient rank could take place in this stage. On average, however, all these patterns are comparable and in line with the studies' outcomes discussed in the literature review section (see also, Myeller and Plug, 2006; Lykins et al., 2006; Bodenmann and Ledermann, 2007; Witting et al., 2008; Bancroft, 2009; Loureiro et al., 2009; Carvalho and Nobre, 2011; Hooghe, 2011).

\section{Estimation framework}

Sexual activity may not casually impact wages. That is, one could suggest that the strength of an individual's sexual activity may in fact be endogenous; higher wages may encourage some to adopt more sexually active lives. For instance, higher wages may increase the value and attractiveness of a person on the dating market; higher wages may increase purchase of gifts that are thanked for via sex. Unfortunately, there are no references with which to address these claims, other than Blanchflower and 
Oswald (2004), who suggest that increased income does not translate into additional sex.

A standard approach to address endogeneity is to undertake a two-stage estimation, as in Davidson and MacKinnon (2004), Cameron and Pravin (2005), and Sabia and Rees (2008) where we estimate a sexual activity equation with the appropriate instruments in the first stage. In the second stage, we insert the predicted values into the wage equation. The preference equation is identified using appropriate instruments that capture the influence of prior experiences or preferences, and the credibility of this strategy rests on our ability to identify a set of valid instruments, which are excluded from the second stage.

The structure of the two-stage variable estimation is of the typical form (Wooldridge, 2006):

$$
\begin{array}{lr}
W_{i}=a+\boldsymbol{\gamma} \hat{S}_{i}+\boldsymbol{\beta} Y_{i}+\varepsilon_{i} & \text { Equation 1: Wage equation } \\
S_{i}=a+\boldsymbol{\varphi} X_{i}+\boldsymbol{\beta} Y_{i}+e_{i} & \text { Equation 2: Preference - sexual activity equation }
\end{array}
$$

where $W_{i}$ denotes the outcome variable of interest; $Y_{i}$ denotes the observed control variables; $S_{i}$ denotes the treatment variable; $X_{i}$ denotes the preference equation's instruments; $\beta, \gamma$ and $\varphi$ are the corresponding parameter vectors to be estimated; $\varepsilon_{\mathrm{i}}$ and $e_{i}$ are error terms that represent additional unobserved effects, measurement effects, etc. The coefficient of interest is $\gamma$. A statistically significant positive coefficient of $\gamma$ would result in higher wages.

The instruments evaluated in this study include the following: whether individuals believe in God (any) and attend religious services at least 2 times per month. 
Academic studies suggest that sexual activity is affected by religious affiliation. Premarital sex, sexual activity, sexual experience, divorce, marital and extramarital sexual relationships are negatively affected by religious affiliation and religious attendance (Billy, 1994; Blinn-Pike, 1999; Wade, 2002; Rostosky et al., 2003). If the appropriate instruments are validated after empirical evaluation they can distinguish the effect of sexual activity on wages from any effect of wages on the decision to have sexual activities (see also, Sabia and Ress, 2008).

Following Wooldridge (2006), in theory, the suitable instruments in the current study must not affect wages other than through the effects of these variables on sexual activity. Furthermore, the instruments must avoid the possibility of reverse causality; they must not be determined by either sexual activity or wages. To be precise, in the current data set, wages should not be affected by an individual's belief in God or attendance of religious services. In addition, belief in God and attendance of religious services should not be affected by sexual activity or wages ${ }^{2}$.

In the current study, we use four methods to test the validity of our instruments (see also, Wooldridge, 2006; Sabia and Rees, 2008).

\footnotetext{
${ }^{2}$ Note that if lower wages were determined by lower religious affiliation, we would then expect that only the well-paid employees would be strongly religiously affiliated. In general, this is not true. In addition, if lower religious affiliation was determined by higher sexual activity, we would then expect that only a small fraction of employees would have religious affiliations, as the employment period (18-65) is the most sexually active period in peoples' lives. In general, this is not true. Moreover, if lower religious affiliation was determined by lower wages, we would then expect that only employees with strong religious affiliations would be well-paid. In general, this is not true.
} 
[1] First, we examine whether the instruments; believe in God and religious services attendance, are individually or jointly significant predictors of sexual activity (Table 2).

[2] Second, we examine whether wages are individually or jointly affected by the instruments (Table 3), and whether each instrument is affected by sexual activity status (Table 4).

[3] Third, because the preference equation's instruments $X_{i}$, contains multiple instruments, we are able to conduct over-identification tests that examine whether the instruments are correlated with the residual of the wage equation (Table 5).

[4] Fourth, we provide a set of falsification tests that focus on several outcomes correlated with wages but that, in theory, should not be impacted by sexual activity (Table 8).

The final structure of the instrumental variable model is of the form (see, Sabia and Rees, 2008):

$W_{i}=a+\gamma S_{i}+\beta Y_{i}+\hat{\delta} e_{i}+\varepsilon_{i}$ Equation 3: two-stage equation

if $\hat{\delta}$ is statistically significant different from zero, $S_{i t}$ would be endogenous.

\section{Outcomes and discussion}

\section{4.a First stage estimations; The formation of sexual activity}

Estimates of sexual activity equation are presented in Table 2. For both sexes, believe in God and attend religious services appear to be good predictors of sexual activity. The estimated coefficients of the variables in $X_{i}$ are uniformly significant at 
conventional levels, and also jointly significant predictors of sexual activity. There is a negative and statistically significant correlation at the $1 \%$ level between belief in God and sexual activity, as well as between attendance of religious services and sexual activity. The significance of these outcomes verifies the conclusions of the literature discussed above (Billy, 1994; Blinn-Pike, 1999; Wade, 2002; Rostosky et al., 2003) and the validity of the instrumental variables selected.

Moreover, an individuals’ age seems to have an insignificant effect. However, if we consider a set of dummy variables, we can estimate that individuals between 26 and 50 years old exhibit statistically significantly higher sexual activity at the $1 \%$ level. Furthermore, men seem to have statistically significantly more sexual activities than women, other things being equal, at the $5 \%$ level. In addition, marital status shows a positive and statistically significant effect on sexual activity at the $1 \%$ level. These two patterns are standard outcomes in the literature reviewed. Furthermore, homosexuality does not entail different levels of sexual activity. Immigrants' sexual activity, however, is statistically significantly lower than that of natives, at the $10 \%$ level. In addition, people having health limitations (i.e. disabilities, daily medications etc) have statistically significant lower levels of sexual activity. Furthermore, higher education (university or technical college degree) and employment status do not seem to affect employees' sexual activity. In addition, extraversion (i.e. sociable, outgoing, energetic etc) has a statistically significant effect on sexual activity. Additionally, if we consider separate regression results for each sex, shown in Panels II and III, some interesting results are found. Women's religious affiliation has a more negative effect on their sexual activity than men's does. The age coefficient for women between 26 and 50 years of age is lower than that of men; that is, with respect to age, returns to sexual 
activity are lower for women than for men. All of these relationships are observed in the medical and psychological literature reviewed in this study. Finally, migrant women's sexual activity is higher than that of migrant men.

\section{[Table 2]}

\section{4.b Over-identification tests, and second stage estimations}

To continue with, in Table 3 we observe that the selected instruments (believe in God and religious services attendance) are unrelated to wages individually and jointly. In addition, in Table 4 we observe that each instrument is not affected by wages. The robustness tests show that the instruments are valid since the theoretical criteria are fulfilled.

\section{[Table 3] - [Table 4]}

In Table 5 the Sargan (1958) - Hansen (1982) over-identification test provides support for excluding the instruments from the second-stage equation, and we ultimately find that sexual activity is not endogenous under the current sample and framework. Regarding the estimations, the regression outcomes suggest that wages are positively affected by sexual activity, at the $1 \%$ significance level. For both sexes, in Panel I, we observe that a one standard deviation increase in sexual activity increases hourly wages by 3.2\%, other things being equal. For men (women), in Panel II (III), we observe that a one standard deviation increase in sexual activity increases hourly wages by 3.8\% (3.0\%), other things being equal. Similarly, the studies of Blanchflower and Oswald (2004) and Loureiro et al. (2009) suggest that sexual activity positively affects economic outcomes. 
With respect to the other variables of interest, the results in the wage regression stage are as expected. Age and marital status both have positive and statistically significant effects on wages. Men receive statistically significant higher wages than women. Additionally, heterosexual employees receive statistically significant higher wages than homosexuals. Health impaired people face statistically significant lower wages. The same holds for immigrants. Work experience has a positive and statistically significant correlation with wages, and those employees with a university or technical school diploma also receive statistically significant higher wages. Concerning the occupational covariates, those in white-collar jobs receive statistically significant higher wages, and the effect on wages of having a public sector job is also positive and statistically significant. Finally, regarding personality traits, if individuals are characterised by extraversion face statistically significant higher wages. Moreover, the ranking of the parameter coefficients is also interesting. Using Wald tests we can observe that wages are highly positively affected by years of work experience and by higher education, followed by employee age and marital status. Occupations and sectors are of crucial importance. Sexual activity has the lowest positive impact on wage determination, but it is still a statistically significant variable. The importance of the sexual activity variable can also be assessed by the fact that if we regress a single wage equation without the sexual activity variable, the $\mathrm{R}^{2}$ is 0.821 , while if we consider the sexual activity variable (as in Table 5), the $\mathrm{R}^{2}$ is 0.842 . In other words, the wage estimation becomes more precise if we consider the sexual activity variable.

\section{[Table 5]}

In Table 6, we perform additional regressions using sexual activity’s interaction effects (see, Braumoeller, 2004; Brambor et al., 2006). The returns to sexual activity are 
higher for those between 26 and 50 years of age. To be specific, for both sexes (Panel I) we observe that a one standard deviation increase in sexual activity increases hourly wages by $5.4 \%$, other things being equal. This is the only age range where the interaction effects' coefficients are statistically significant at the $10 \%$ level. This pattern holds for both genders. In addition, heterosexuals' sexual activity does not seem to provide higher or lower wage returns than that of homosexuals. Moreover, wages are higher for those health-impaired employees who are sexually active. Furthermore, wages are higher for those with extraversion and openness traits who are sexually active. Finally, the wage returns to sexual activity are not affected by whether individuals have a university or technical school degree, are white-collar employees or work in public sector jobs.

\section{[Table 6]}

In Table 7, we examine the returns to sexual activity based on the frequency of sexual activity. We employ six dummy variables to capture the impact on wages of no sex, sex once or twice a year, sex once a month, sex two to three times a month, sex two to three times a week and sex more than four times a week. The reference category is sex weekly. In general, there is a monotonic relationship between the frequency of sexual activity and wage returns. Those having sex once a month have positive and statistically significant wage returns at the $5 \%$ level. While those engaging in sexual activity two to three times a month or more have positive and statistically significant returns to wages at the $1 \%$ level. The coefficient is higher for those having sex more than four times a week. That is, in Panel I, for both sexes we observe that an increase from sex weekly (reference reference) to sexual activity more than four times a week increases wages by $3.2 \%$. In addition, Table 7 shows that men having no sex receive 
lower wages by $1.0 \%$. Furthermore, married men having no sex receive lower wages by 1.3\%. Both results are statistically significant.

\section{[Table 7]}

\section{4.c Falsification tests}

The estimates discussed above are informative only if the instruments are appropriately excluded from the wage equation. In order to further explore the validity of the instruments, we conduct a series of falsification tests. To be specific, we examine the estimated relationship between sexual activity and three outcomes that are positively and statistically significant correlated with wages ${ }^{3}$ but should be immune from any direct influence of sexual activity. These outcomes are as follows: (1) Living in the capital city (Athens) (2) Working over-time, (3) Working part-time. If estimates indicate that sexual activity is related to one or all of these outcomes, this would be evidence that the instruments are correlated with the unmeasured determinants of wages. Table 8 presents the results of these tests. In no case do we find evidence that sexual activity is related to the outcome in question. This pattern of results adds to our confidence that the instruments are valid and support a causal interpretation of the twostage result in Tables 5, 6 and 7.

\section{[Table 8]}

\section{4.d Wage Decompositions}

In addition, we are interested in examining the role that sexual activity plays with respect to wage gaps between demographic groups. In Table 9, we present the

\footnotetext{
${ }^{3}$ Tables are available on request. See also the sub-correlation matrix (Appendix B).
} 
results of five wage decompositions: men-women, natives-immigrants, heterosexual men-gay men, heterosexual women-lesbian women, healthy employees - disabled employees. As in Yun (2007), we calculate Equation's 3 post-estimations. In Panel I, we present the raw differences. In Panel II, we present the explained differential, and in Panel III, we present the unexplained differential. In Panel IV, we present the residuals effects and in Panel V we present the per cent-wise contribution of sexual activity to the explained wage gap. There are significant wage differences between the majority and minority groups in all cases that cannot be explained by the exogenous variables, and residuals effects. However, in all cases, sexual activity plays a statistically insignificant role in determining the wage gap between the majority and minority groups.

\section{[Table 9]}

\section{4.e Sample selection issues}

Finally, Equation 3, is observed only for those who are employed. Concerns about sample selection biases might be raised. Failing to apply selection correction methods may result in inconsistent estimation. However, given the debate in the econometric literature over the value of sample selection modelling only in this stage do we offer estimates considering selection and endogeneity. As we observe in Table 10, either way, with or without Inverse Mills Ration (IMR), the results from the wage equation do not change qualitatively. Methodologically, as in Jäckle and Himmler (2010) and Semykina and Wooldridge (2010) we can calculate the IMR estimating a probit model for the employment participation individuals ${ }^{4}$. Semykina and Wooldridge (2010) enhance Wooldridge's (1995) estimator and demonstrate how to test and control

\footnotetext{
${ }^{4}$ Tables are available on request.
} 
for sample selection in a model with endogeneity. The exclusion restrictions we propose are: (1) Non labour income, (2) Dummies for the highest educational attainment of the respondent's mother and father. Specification approaches and over-identification tests as in Tables 2, 3, 4 and 5 accept the null hypothesis of no correlation between the instruments and the error of the wage equation ${ }^{5}$. Indeed, while it is plausible to assume that non labour income, and parents' education is associated to a respondent's employment probability it is not likely that it will affect the respondent's wage itself. However, it should be kept in mind that the effects we measure in our sample of employed individuals cannot be fully generalized to the total population without reservation.

\section{[Table 10]}

\section{Conclusive remarks}

The purpose of the analysis was to examine whether sexual activity is associated with wages. The estimations suggested that there is a monotonic relationship between the frequency of sexual activity and wage returns. Those employees having sex more than four times a week receive statistically significant highest wages. Moreover, the outcomes suggested that wage returns to sexual activity are statistically significant higher for those between 26 and 50 years of age. In addition, heterosexuals' sexual activity does not seem to provide higher or lower wage returns than that of homosexuals. Whilst, wages are higher for those health-impaired employees who are sexually active. Conversely, wage returns to sexual activity are not affected by higher education status, occupation or sector of employment.

\footnotetext{
${ }^{5}$ Tables are available on request.
} 
In this study, we hypothesised that because the medical and psychological literature suggest that sexual activity is associated with good health, endurance, mental well-being, mental capacities and dietary habits, it could be perceived as a health indicator, which might influence returns to labour market activity. The rationale was that the economics literature suggests that physical and mental health, as well as personality characteristics, are important factors that affect wages. The patterns found in this study strengthen this reasoning. Indeed, based on the Maslow's (1954) Need Hierarchy Theory individuals are born with a set of needs. There are five needs: physiological, safety, belongingness, esteem and self-actualization. Maslow (1954) theorised that basic needs such as food, water, and sexual activity must be met before any other motivations occur. If basic needs are not satisfied, human beings cannot function. That is, other successively influential needs for esteem and self-actualisation follow with increasing levels of motivations after basic needs are met. Maslow’s (1954) Need Hierarchy Theory claims that the happier and more fulfilled individuals are in their lives, the more productive and successful they will be in their work, translating to higher wages. The theory concludes that people need to love and be loved (sexually and non-sexually) by others. In the absence of these elements, many people become susceptible to loneliness, social anxiety, and depression that affect their working life. As we discussed, sexual activity is a key aspect of personal health and social welfare that influences individuals across their life span. In terms of policy implications, access to effective, broadly-based sexual health education could be an important contributing factor to the health and well-being of people.

The current study advances the literature. Although, few studies suggest that the frequency sexual activity is positively related to wages it is unclear whether this 
correlation represents a causal relationship or can be explained by unmeasured heterogeneity. Using two stage estimations the outcomes suggest that there is a positive relation between sexual activity and wages. Importantly, instrumental variables estimates are robust across instrument choice, a range of robustness checks, and a number of falsification tests. Whilst, selection issues are also considered. However, since the current findings are strictly applicable only to the time, place, individual characteristics from which the sample was drawn, we should highlight that the reported results are simply an indication of the relationship between sexual activity and wages but are by no means the final word.

To conclude this study, sexual activity may be of interest to economists, and it may serve as a framework for integrating the existing evidence, as well as for structuring future research efforts. Indeed, contemporary social analysis suggests that health, cognitive and non-cognitive skills and personality are important factors that affect wage level, life and job satisfaction, cognitive functioning and reasoning ability. Sexual activity may also be of interest to social scientists, since sexual activity is considered to be a barometer for health, quality of life, well-being and happiness. Social scientists can take advantage of this parameter in order to shed light on individuals' needs. 


\section{References}

Acemoglu, D. Angrist, J. D. (2001). Consequence of Employment Protection? The Case of Americans with Disabilities Act. Journal of Political Economy 19(5): 915-950.

Baldwin, L. M. and Johnson, W. G. (2000). Labour Market Discrimination Against Men with Disabilities in the Year of the ADA. Southern Economic Journal, 66(3): 548566.

Bancroft, J. (2009). Human Sexuality and its Problems. Edinburgh: Elsevier.

Becker, G. S. (1975). Human Capital: A Theoretical and Empirical Analysis, with Special Reference to Education. New York: Columbia University Press.

Billy, J. O. G. (1994). Contextual Effects on the Sexual Behavior of Adolescent Women. Journal of Marriage and Family, 56(2): 387-404.

Blanchflower, D. G. and Oswald, A. J. (2004). Money, Sex and Happiness: An Empirical Study. Scandinavian Journal of Economics, 106(3): 393-414.

Blinn-Pike, L. (1999). Why Abstinent Adolescents Report They Have Not Had Sex: Understanding Sexually Resilient Youth. Family Relations, 48(3): 295-301.

Bodenmann, G. and Ledermann, T. (2007). Depressed Mood and Sexual Functioning. International Journal of Sexual Health, 19(4): 63-74.

Brambor, T. Clark, W. R. and Golder, M. (2006). Understanding Interaction Models: Improving Empirical Analyses. Political Analysis, 14(1): 63-82.

Braumoeller, B. (2004). Hypothesis Testing and Multiplicative Interaction Terms. International Organization, 58(4): 807-820.

Brody, S. (2010). The Relative Health Benefits of Different Sexual Activities. The Journal of Sexual Medicine, 7(4): 1336-1361. 
Cameron, A. C. and Pravin K. T. (2005). Microeconometrics: Methods and Applications. Cambridge University Press, Cambridge.

Campolieti, M. (2002). Disability and the Labour Force Participation of Older Men in Canada. Labour Economics, 9(3): 405-433.

Carpenter, C. S. (2005). Self-Reported Sexual Orientation and Earnings: Evidence from California. Industrial and Labour Relations Review, 58(2): 258-273.

Carvalho, J. and Nobre, P. (2011). Predictors of Men’s Sexual Desire: The Role of Psychological, Cognitive-Emotional, Relational, and Medical Factors. Journal of Sex Research, 48(2-3): 254-262.

Cawley, J. Heckman, J. and Vytlacil, E. (2001). Three Observations on Wages and Measured Cognitive Ability. Labour Economics, 8(4): 419-442.

Cawley, J. (2004). The Impact of Obesity on Wages. Journal of Human Resources, 39(2): 451-474.

Costa, R. M. and Brody, S. (2007). Women’s Relationship Quality is Associated with Specifically Penile-Vaginal Intercourse Orgasm and Frequency. Journal of Sex and Marital Therapy, 33(4): 319-327.

Davidson, R. and MacKinnon, G. J. (2004). Econometric Theory and Methods. Oxford University Press, Oxford.

Digman, J. M. (1990). Personality Structure: Emergence of the Five-Factor Model. Annual Review of Psychology, 41: 417-40.

Ellison, C. R. (2000). Women's Sexualities. Oakland: New Harbinger Publications, Inc. Gribble, J. N. Miller, G. H. Rogers, S. H. and Turner, F. C. (1999). Interview Mode and Measurement of Sexual Behaviors: Methodological Issues. Journal of Sex Research, 36(1): 16-24. 
Han, E. Norton, E. C. and Stearns, S. C. (2009). Weight and Wages: Fat Versus Lean Paychecks. Health Economics, 18(5): 535-548.

Hansen, L.P. (1982). Large Sample Properties of Generalized Method of Moments Estimators. Econometrica, 50(4): 1029-1054.

Heineck, G. and Anger, S. (2010). The Returns to Cognitive Abilities and Personality Traits in Germany. Labour Economics, 17(3): 535-546.

Heineck, S. and Anger, G. (2010). The Returns to Cognitive Abilities and Personality Traits in Germany. Labour Economics, 17(3): 535-546.

Hooghe, M. (2011). Is Sexual Well-Being Part of Subjective Well-Being? An Empirical Analysis of Belgian (Flemish) Survey Data Using an Extended Well-Being Scale. Journal of Sex Research, DOI: 10.1080/00224499.2010.551791.

Jäckle, R. and Himmler, O. (2010). Health and Wage: Panel Data Estimates Considering Selection and Endogeneity. Journal of Human Resources, 45(2): 364-406.

Jones, K. M. Latreille, P. L. Sloane, P. J. (2006). Disability, Gender, and the British Labour Market. Oxford Economic Papers, 58(3): 407-449.

Lindau, S. T. Schumm, P. Laumann, E. O. Levinson, W. O’Muircheartaigh, C. Waite, L. (2007). A Study of Sexuality and Health Among Older Adults in the US. New England Journal of Medicine, 357(8): 762-774.

Lindau, S. T. and Gavrilova, N. (2010). Sex, Health, and Years of Sexually Active Life Gained Due to Good Health: Evidence from Two US Population Based Cross Sectional Surveys of Ageing. British Medical Journal, 340:c810. 
Loureiro, P. R. A. Orrillo, J. de Mendonca, M. J. C. and Moreira, T. B. S. (2009). Impact of Sexual Activity on Wage: An Empirical Investigation. Economia $e$ Desenvolvimento, Recife (PE), 8(2): 239-251.

Lykins, A. M. Janssen, E. Graham, A. C. (2006). The Relationship Between Negative Mood and Sexuality In Heterosexual College Women and Men. The Journal of Sex Research, 43(2): 136-143.

Maslow, A. (1954). Motivation and Personality. New York: Harper and Row New York.

McCrae, R. R. and John, O. P. (1992). An Introduction to the Five-Factor Model and its Applications. Journal of Personality, 60(2): 175-215.

Michael, R. T. Gagnon, J. H. Laumann, E. O. and Kolata, G. (1994). Sex in America: A Definitive Survey. Little, Brown, Boston, MA.

Mincer, J. (1958). Investment in Human Capital and Personal Income Distribution. Journal of Political Economy, 66(4): 281-302.

Mueller, G. and Plug, E. J. S. (2006). Estimating the Effect of Personality on Male and Female Earnings. Industrial and Labor Relations Review, 60(1): 3-22.

Norton, E. C. and Han, E. (2008). Genetic Information, Obesity, and Labor Market Outcomes. Health Economics, 17(9): 1089-1104.

Onder, G. Penninx, B. Guralnik, J. M. Jones , H. Fried, L. P. Pahor, M. Williamson, J. D. (2003). Sexual Satisfaction and Risk of Disability in Older Women. Journal of Clinical Psychiatry, 64(10): 1177-1182.

Palmore, E. (1982). Predictors of the Longevity Difference: A Twenty-Five Year Follow-Up. The Gerontologist, 22(6): 513-518. 
Paunonen, S. V. and Ashton, M. C. (2001). Big Five Factors and Facets and the Prediction of Behavior. Journal of Personality and Social Psychology, 81(3): 524539.

Planned Parenthood Federation of America. (2003). The Health Benefits of Sexual Expression. New York.

Rostosky, S. S. Regnerus, M. D. and Wright, M. L. C. (2003). Coital Debut: The Role of Religiosity and Sex Attitudes in the Add Health Survey. Journal of Sex Research, 40(4): 358-367

Sabia, J. J. and Rees, D. I. (2008). The Effect of Adolescent Virginity Status on Psychological Well-Being. Journal of Health Economics, 27(5): 1368-1381.

Sargan, J.D. (1958). The Estimation of Economic Relationships Using Instrumental Variables. Econometrica, 26(3): 393-415.

Semykina, A. and Wooldridge, J. M. (2010). Estimating Panel Data Models in the Presence of Endogeneity and Selection. Journal of Econometrics, 157(2): 375380.

Vrangalova, Z. and Savin-Williams, R. C. (2011). Adolescent Sexuality and Positive Well-Being: A Group-Norms Approach. Journal of Youth and Adolescence, 40(8):931-944.

Wade, L. D. (2002). Relationship Dissolution as a Life Stage Transition: Effects on Sexual Attitudes and Behaviors. Journal of Marriage and Family, 64(4): 898-914.

Witting, K. Santtila, P. Varjonen, M. Jern, P. Johansson, A. and Von Der Pahlen, B. Kenneth Sandnabba, K. (2008). Couples’ Sexual Dysfunctions: Female Sexual Dysfunction, Sexual Distress, and Compatibility with Partner. The Journal of Sexual Medicine, 5(11): 2587-2599. 
Wooldridge, J. M. (1995). Selection Correction for Panel Data Models under Conditional Mean Independence Assumption. Journal of Econometrics, 68(1): 115132.

Wooldridge, J. M. (2006). Introductory Econometrics: a Modern Approach. Florence, Thomson, South-Western.

Yun, M.-S. (2007). An Extension of the Oaxaca Decomposition Using Generalized Residuals. Journal of Economic and Social Measurement, 32(1), 15-22. 


$\begin{array}{lll}\text { Panel I } & \text { Panel II } & \text { Panel III }\end{array}$

\begin{tabular}{|c|c|c|c|c|c|c|}
\hline $\begin{array}{l}\text { Variable } \\
\text { name }\end{array}$ & $\begin{array}{l}\text { Total } \\
\text { sample } \\
\text { Men and } \\
\text { Women }\end{array}$ & $\begin{array}{l}\text { Standard } \\
\text { deviation }\end{array}$ & Men & $\begin{array}{l}\text { Standard } \\
\text { deviation }\end{array}$ & Women & $\begin{array}{l}\text { Standard } \\
\text { Deviation }\end{array}$ \\
\hline Observations & 6,317 & - & 2,997 & - & 3,320 & - \\
\hline Sexual activity & 3.98 & 1.11 & 4.07 & 1.11 & 3.89 & 1.11 \\
\hline Hourly wages (€) & 7.97 & 3.49 & 8.20 & 3.95 & 7.76 & 2.98 \\
\hline Age & 34.33 & 11.58 & 33.32 & 11.55 & 35.29 & 11.54 \\
\hline Men & $47.44 \%$ & 0.49 & - & - & - & - \\
\hline Homosexuality & $5.57 \%$ & 0.29 & $5.89 \%$ & 0.29 & $5.26 \%$ & 0.29 \\
\hline Married & $58.33 \%$ & 0.49 & $52.15 \%$ & 0.49 & $64.21 \%$ & 0.47 \\
\hline Migrants & $15.41 \%$ & 0.30 & $12.55 \%$ & 0.31 & $18.12 \%$ & 0.36 \\
\hline Employed & $78.10 \%$ & 0.41 & $80.24 \%$ & 0.39 & $74.17 \%$ & 0.42 \\
\hline $\begin{array}{l}\text { Labour force } \\
\text { participants }\end{array}$ & $93.16 \%$ & 0.25 & $97.26 \%$ & 0.16 & $89.45 \%$ & 0.30 \\
\hline $\begin{array}{l}\text { Actual working } \\
\text { experience }\end{array}$ & 13.22 & 10.54 & $12.84 \%$ & 10.74 & 13.58 & 10.33 \\
\hline White collar jobs & $39.12 \%$ & 0.48 & $36.83 \%$ & 0.48 & $42.05 \%$ & 0.49 \\
\hline Public jobs & $52.17 \%$ & 0.49 & $37.75 \%$ & 0.48 & $66.66 \%$ & 0.47 \\
\hline $\begin{array}{l}\text { University or technical } \\
\text { school degree }\end{array}$ & $47.90 \%$ & 0.49 & $49.85 \%$ & 0.50 & $49.22 \%$ & 0.50 \\
\hline Disability status & $7.72 \%$ & 0.26 & $7.72 \%$ & 0.26 & $7.09 \%$ & 0.30 \\
\hline Daily medication & $29.13 \%$ & 0.15 & $27.22 \%$ & 0.15 & $33.12 \%$ & 0.16 \\
\hline Diabetes & $15.76 \%$ & 0.11 & $15.16 \%$ & 0.12 & $17.28 \%$ & 0.11 \\
\hline Heart diseases & $6.11 \%$ & 0.25 & $6.05 \%$ & 0.23 & $5.38 \%$ & 0.25 \\
\hline Arthritis & $2.32 \%$ & 0.15 & $2.28 \%$ & 0.14 & $3.18 \%$ & 0.18 \\
\hline Cancer & $0.48 \%$ & 0.08 & $0.41 \%$ & 0.06 & $0.62 \%$ & 0.06 \\
\hline Believe in God & $85.12 \%$ & 0.73 & $82.66 \%$ & 0.72 & $87.33 \%$ & 0.76 \\
\hline $\begin{array}{l}\text { Religious services } \\
\text { attendance }\end{array}$ & $23.43 \%$ & 0.30 & $21.44 \%$ & 0.31 & $25.13 \%$ & 0.21 \\
\hline Extraversion & 4.27 & 1.08 & 4.36 & 1.08 & 4.14 & 1.07 \\
\hline Agreeableness & 5.18 & 1.08 & 5.10 & 0.99 & 5.23 & 1.04 \\
\hline Conscientiousness & 5.21 & 1.00 & 5.21 & 1.54 & 5.60 & 1.64 \\
\hline Emotional stability & 5.12 & 0.96 & 5.11 & 0.95 & 5.44 & 1.00 \\
\hline Openness & 4.12 & 0.94 & 4.39 & 1.07 & 4.07 & 1.03 \\
\hline $\begin{array}{l}\text { Non-labour income } \\
\text { (monthly) }(€)\end{array}$ & 234.46 & 28.46 & 237.83 & 36.30 & 242.48 & 20.23 \\
\hline $\begin{array}{l}\text { Mother university or } \\
\text { technical school degree }\end{array}$ & $16.70 \%$ & 0.25 & $17.36 \%$ & 0.29 & $16.40 \%$ & 0.28 \\
\hline $\begin{array}{l}\text { Father university or } \\
\text { technical school degree }\end{array}$ & $20.58 \%$ & 0.31 & $20.49 \%$ & 0.35 & $21.04 \%$ & 0.25 \\
\hline
\end{tabular}




\section{Panel I}

Panel II

Panel III

Total Sample

Men

Women

Men and

Women

\begin{tabular}{|c|c|c|c|}
\hline Age & $0.029(0.020)$ & $0.031(0.021)$ & $0.029(0.020)$ \\
\hline $18-25$ years of age & $0.021(0.013)$ & $0.025(0.014)$ & $0.020(0.014)$ \\
\hline $26-50$ years of age & $0.026(0.012)^{* * *}$ & $0.034(0.009) * * *$ & $0.026(0.010) * * *$ \\
\hline 52-65 years of age & $0.017(0.015)$ & $0.015(0.011)$ & $0.009(0.019)$ \\
\hline Men & $0.116(0.068)^{* *}$ & - & - \\
\hline Homosexuality & $0.037(0.020)$ & $0.039(0.021)$ & $0.030(0.024)$ \\
\hline Married & $0.204(0.041)^{* * *}$ & $0.216(0.039) * * *$ & $0.206(0.050)^{* * *}$ \\
\hline Migrants & $-0.052(0.030) * *$ & $-0.064(0.038)^{* *}$ & $-0.024(0.015) *$ \\
\hline Disability status & $-0.130(0.045)^{* * *}$ & $-0.127(0.036)^{* * *}$ & $-0.174(0.044)^{* * *}$ \\
\hline Daily medication & $-0.054(0.008)^{* * *}$ & $-0.052(0.012)^{* * *}$ & $-0.064(0.007) * * *$ \\
\hline Diabetes & $-0.024(0.011)^{* * *}$ & $-0.021(0.010)^{* * *}$ & $-0.031(0.010)^{* * *}$ \\
\hline Heart diseases & $-0.114(0.025)^{* * *}$ & $-0.104(0.033) * * *$ & $-0.168(0.041) * * *$ \\
\hline Arthritis & $-0.039(0.013)^{* * *}$ & $-0.034(0.014)^{* * *}$ & $-0.042(0.012)^{* * *}$ \\
\hline Cancer & $-0.149(0.021)^{* * *}$ & $-0.120(0.019) * * *$ & $-0.188(0.018) * * *$ \\
\hline $\begin{array}{l}\text { Psychiatric / psychological } \\
\text { symptoms }\end{array}$ & $-0.037(0.013)^{* * *}$ & $-0.039(0.010)^{* * *}$ & $-0.037(0.010)^{* * *}$ \\
\hline $\begin{array}{l}\text { University or technical } \\
\text { school degree }\end{array}$ & $0.043(0.037)$ & $0.045(0.030)$ & $0.040(0.038)$ \\
\hline Actual working experience & $0.025(0.018)$ & $0.029(0.019)$ & $0.029(0.021)$ \\
\hline White collar & $0.031(0.027)$ & $0.035(0.027)$ & $0.033(0.027)$ \\
\hline Public jobs & $0.028(0.020)$ & $0.026(0.021)$ & $0.028(0.020)$ \\
\hline God belief & $-0.086(0.027)^{* * *}$ & $-0.072(0.030)^{* * *}$ & $-0.091(0.036)^{* * *}$ \\
\hline Religious service attendance & $-0.042(0.019)^{* * *}$ & $-0.040(0.016)^{* * *}$ & $-0.051(0.008) * * *$ \\
\hline Extraversion & $0.010(0.003)^{* * *}$ & $0.012(0.005)^{* * *}$ & $0.009(0.004)^{* * *}$ \\
\hline Agreeableness & $0.005(0.010)$ & $0.007(0.006)$ & $0.010(0.010)$ \\
\hline Conscientiously & $0.008(0.010)$ & $0.005(0.004)$ & $0.011(0.009)$ \\
\hline Emotional stability & $0.012(0.009)$ & $0.010(0.008)$ & $0.013(0.010)$ \\
\hline Openness & $0.004(0.006)$ & $0.005(0.005)$ & $0.013(0.011)$ \\
\hline $\begin{array}{l}\text { F-statistic on joint } \\
\text { significance of instrument }\end{array}$ & $12.011(1.203)^{* * *}$ & $9.101(1.921)^{* * *}$ & $13.992(1.661)^{* * *}$ \\
\hline $\mathrm{R}^{2}$ & 0.734 & 0.716 & 0.720 \\
\hline Observations & 6,317 & 2,997 & 3,320 \\
\hline
\end{tabular}

Notes: Data set; 2008 Greek Behavioural Study. Standard errors are in parenthesis. *Significant at the $10 \%$ level. ** Significant at the 5\% level. *** Significant at the $1 \%$ level. 


$\begin{array}{lrr} & \text { Wages } & \\ \text { Panel I } & \text { Panel II } & \text { Panel III }\end{array}$

Total Sample Men $\quad$ Women
Men and

\begin{tabular}{|c|c|c|c|}
\hline Age & $0.304(0.058)^{* * *}$ & $0.316(0.044)^{* * *}$ & $0.300(0.051)^{* * *}$ \\
\hline Age $^{2}$ & $-0.000(0.000)^{* * *}$ & $-0.000(0.000)^{* * *}$ & $-0.000(0.000)^{* * *}$ \\
\hline Men & $0.078(0.021)^{* * *}$ & - & - \\
\hline Homosexuality & $-0.087(0.030)^{* * *}$ & $-0.085(0.035) * * *$ & $-0.092(0.041)^{* * *}$ \\
\hline Married & $0.106(0.040)^{* * *}$ & $0.105(0.041) * * *$ & $0.100(0.042)^{* * *}$ \\
\hline Migrants & $-0.117(0.022)^{* * *}$ & $-0.110(0.024) * * *$ & $-0.186(0.025)^{* * *}$ \\
\hline Disability status & $-0.183(0.050)^{* * *}$ & $-0.163(0.053)^{* * *}$ & $-0.203(0.068)^{* * *}$ \\
\hline Daily medication & $-0.090(0.037)^{* * *}$ & $-0.084(0.045) * *$ & $-0.125(0.054) * * *$ \\
\hline Diabetes & $-0.094(0.047)^{*}$ & $-0.093(0.047)^{*}$ & $-0.116(0.061)^{*}$ \\
\hline Heart diseases & $-0.087(0.045)^{* *}$ & $-0.078(0.040)^{*}$ & $-0.120(0.064)^{* *}$ \\
\hline Arthritis & $-0.043(0.025)^{*}$ & $-0.040(0.022) *$ & $-0.044(0.025)^{*}$ \\
\hline Cancer & $-0.097(0.048)^{* *}$ & $-0.095(0.049) * *$ & $-0.096(0.048)^{* *}$ \\
\hline $\begin{array}{l}\text { Psychiatric / psychological } \\
\text { symptoms }\end{array}$ & $-0.043(0.022) *$ & $-0.043(0.024) *$ & $-0.045(0.024)^{* *}$ \\
\hline $\begin{array}{l}\text { University or technical } \\
\text { school degree }\end{array}$ & $0.350(0.106)^{* * *}$ & $0.378(0.086)^{* * *}$ & $0.345(0.087)^{* * *}$ \\
\hline Actual working experience & $0.364(0.052)^{* * *}$ & $0.378(0.086)^{* * *}$ & $0.345(0.087) * * *$ \\
\hline Actual working experience ${ }^{2}$ & $-0.000(0.000)^{* * *}$ & $-0.000(0.000)^{* * *}$ & $-0.000(0.000)^{* * *}$ \\
\hline White collar & $0.218(0.061)^{* * *}$ & $0.221(0.064)^{* * *}$ & $0.215(0.057) * * *$ \\
\hline Public jobs & $0.254(0.103)^{* * *}$ & $0.268(0.119)^{* * *}$ & $0.245(0.107)^{* * *}$ \\
\hline Sexual activity & $0.032(0.015)^{* * *}$ & $0.039(0.015) * * *$ & $0.030(0.012)^{* * *}$ \\
\hline God belief & $0.024(0.072)$ & $0.024(0.020)$ & $0.023(0.019)$ \\
\hline Religious service attendance & $0.020(0.019)$ & $0.021(0.018)$ & $0.020(0.018)$ \\
\hline Extraversion & $0.012(0.004)^{* * *}$ & $0.017(0.005) * * *$ & $0.009(0.005) * *$ \\
\hline Agreeableness & $0.010(0.010)$ & $0.010(0.009)$ & $0.012(0.011)$ \\
\hline Conscientiously & $0.005(0.009)$ & $0.005(0.010)$ & $0.008(0.008)$ \\
\hline Emotional stability & $0.010(0.009)$ & $0.010(0.008)$ & $0.009(0.007)$ \\
\hline Openness & $0.007(0.005)$ & $0.008(0.007)$ & $0.010(0.008)$ \\
\hline $\begin{array}{l}\text { F-statistic on joint } \\
\text { significance of instrument }\end{array}$ & $0.491(0.346)$ & $0.405(0.316)$ & $0.457(0.433)$ \\
\hline $\mathrm{R}^{2}$ & 0.839 & 0.841 & 0.819 \\
\hline Observations & 4,932 & 2,405 & 2,527 \\
\hline
\end{tabular}

Notes: Data set; 2008 Greek Behavioural Study. Standard errors are in parenthesis. *Significant at the 10\% level. ** Significant at the $5 \%$ level. *** Significant at the $1 \%$ level. 


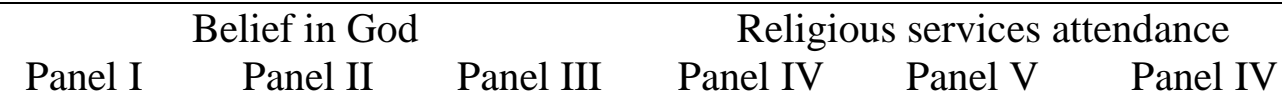

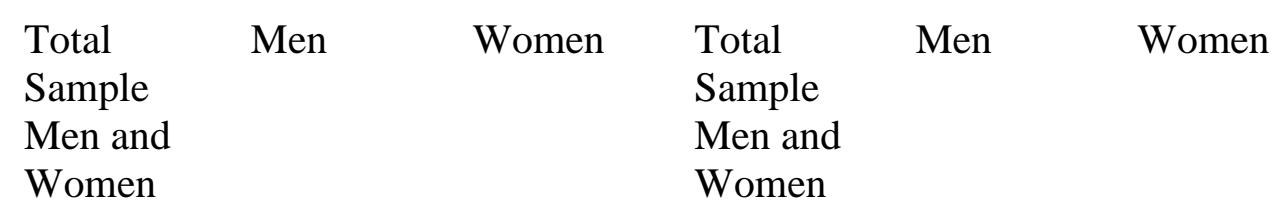

\begin{tabular}{|c|c|c|c|c|c|c|}
\hline Sexual activity & $\begin{array}{l}0.032 \\
(0.029)\end{array}$ & $\begin{array}{l}0.037 \\
(0.029)\end{array}$ & $\begin{array}{l}0.028 \\
(0.026)\end{array}$ & $\begin{array}{l}-0.007 \\
(0.006)\end{array}$ & $\begin{array}{l}0.010 \\
(0.008)\end{array}$ & $\begin{array}{l}-0.008 \\
(0.006)\end{array}$ \\
\hline Age & $\begin{array}{l}0.463 \\
(0.130) * * *\end{array}$ & $\begin{array}{l}0.404 \\
(0.104)^{* * *}\end{array}$ & $\begin{array}{l}0.512 \\
(0.098) * * *\end{array}$ & $\begin{array}{l}0.273 \\
(0.047) * * *\end{array}$ & $\begin{array}{l}0.252 \\
(0.036) * * *\end{array}$ & $\begin{array}{l}0.316 \\
(0.057)^{* * *}\end{array}$ \\
\hline Men & $\begin{array}{l}-0.147 \\
(0.030)^{* * *}\end{array}$ & - & - & $\begin{array}{l}-0.155 \\
(0.058) * * *\end{array}$ & - & - \\
\hline Homosexuality & $\begin{array}{l}0.004 \\
(0.012)\end{array}$ & $\begin{array}{l}-0.006 \\
(0.009)\end{array}$ & $\begin{array}{l}0.005 \\
(0.005)\end{array}$ & $\begin{array}{l}0.012 \\
(0.012)\end{array}$ & $\begin{array}{l}0.010 \\
(0.008)\end{array}$ & $\begin{array}{l}0.012 \\
(0.009)\end{array}$ \\
\hline Married & $\begin{array}{l}0.069 \\
(0.031)^{* * *}\end{array}$ & $\begin{array}{l}0.063 \\
(0.028) * * *\end{array}$ & $\begin{array}{l}0.094 \\
(0.031)^{* * *}\end{array}$ & $\begin{array}{l}0.056 \\
(0.040)\end{array}$ & $\begin{array}{l}0.056 \\
(0.032)\end{array}$ & $\begin{array}{l}0.086 \\
(0.058)\end{array}$ \\
\hline Migrants & $\begin{array}{l}0.064 \\
(0.034)^{* *}\end{array}$ & $\begin{array}{l}0.065 \\
(0.015)^{* *}\end{array}$ & $\begin{array}{l}0.112 \\
(0.032) * * *\end{array}$ & $\begin{array}{l}0.064 \\
(0.037)^{* *}\end{array}$ & $\begin{array}{l}0.065 \\
(0.032)^{* *}\end{array}$ & $\begin{array}{l}0.072 \\
(0.025) * * *\end{array}$ \\
\hline Disability status & $\begin{array}{l}0.059 \\
(0.023) * * *\end{array}$ & $\begin{array}{l}0.062 \\
(0.026) * * *\end{array}$ & $\begin{array}{l}0.067 \\
(0.028) * * *\end{array}$ & $\begin{array}{l}0.032 \\
(0.019) * * *\end{array}$ & $\begin{array}{l}0.030 \\
(0.013) * * *\end{array}$ & $\begin{array}{l}0.037 \\
(0.014)^{* * *}\end{array}$ \\
\hline Daily medication & $\begin{array}{l}0.044 \\
(0.010) * * *\end{array}$ & $\begin{array}{l}0.045 \\
(0.010) * * *\end{array}$ & $\begin{array}{l}0.052 \\
(0.011)^{* * *}\end{array}$ & $\begin{array}{l}0.024 \\
(0.009) * * *\end{array}$ & $\begin{array}{l}0.025 \\
(0.011) * * *\end{array}$ & $\begin{array}{l}0.020 \\
(0.014) * * *\end{array}$ \\
\hline Diabetes & $\begin{array}{l}0.032 \\
(0.014)^{* * *}\end{array}$ & $\begin{array}{l}0.031 \\
(0.013) * * *\end{array}$ & $\begin{array}{l}0.036 \\
(0.013)^{* * *}\end{array}$ & $\begin{array}{l}0.012 \\
(0.005) * * *\end{array}$ & $\begin{array}{l}0.011 \\
(0.005) * * *\end{array}$ & $\begin{array}{l}0.014 \\
(0.006)^{* * *}\end{array}$ \\
\hline Heart diseases & $\begin{array}{l}0.064 \\
(0.025) * * *\end{array}$ & $\begin{array}{l}0.065 \\
(0.024) * * *\end{array}$ & $\begin{array}{l}0.067 \\
(0.023) * * *\end{array}$ & $\begin{array}{l}0.022 \\
(0.008) * * *\end{array}$ & $\begin{array}{l}0.023 \\
(0.006) * * *\end{array}$ & $\begin{array}{l}0.025 \\
(0.008) * * *\end{array}$ \\
\hline Arthritis & $\begin{array}{l}0.030 \\
(0.012)^{* * *}\end{array}$ & $\begin{array}{l}0.031 \\
(0.015)^{* * *}\end{array}$ & $\begin{array}{l}0.030 \\
(0.016)^{* * *}\end{array}$ & $\begin{array}{l}0.006 \\
(0.003) * * *\end{array}$ & $\begin{array}{l}0.006 \\
(0.003) * * *\end{array}$ & $\begin{array}{l}0.008 \\
(0.002)^{* * *}\end{array}$ \\
\hline Cancer & $\begin{array}{l}0.166 \\
(0.036) * * *\end{array}$ & $\begin{array}{l}0.159 \\
(0.032)^{* * *}\end{array}$ & $\begin{array}{l}0.188 \\
(0.035) * * *\end{array}$ & $\begin{array}{l}0.147 \\
(0.028)^{* * *}\end{array}$ & $\begin{array}{l}0.139 \\
(0.031)^{* * *}\end{array}$ & $\begin{array}{l}0.156 \\
(0.029) * * *\end{array}$ \\
\hline $\begin{array}{l}\text { Psychiatric / } \\
\text { psychological } \\
\text { symptoms }\end{array}$ & $\begin{array}{l}0.064 \\
(0.054)\end{array}$ & $\begin{array}{l}0.061 \\
(0.048)\end{array}$ & $\begin{array}{l}0.067 \\
(0.054)\end{array}$ & $\begin{array}{l}0.013 \\
(0.010)\end{array}$ & $\begin{array}{l}0.010 \\
(0.010)\end{array}$ & $\begin{array}{l}0.014 \\
(0.010)\end{array}$ \\
\hline $\begin{array}{l}\text { University or } \\
\text { technical school } \\
\text { degree }\end{array}$ & $\begin{array}{l}0.006 \\
(0.006)\end{array}$ & $\begin{array}{l}0.006 \\
(0.005)\end{array}$ & $\begin{array}{l}0.004 \\
(0.003)\end{array}$ & $\begin{array}{l}0.009 \\
(0.008)\end{array}$ & $\begin{array}{l}0.007 \\
(0.005)\end{array}$ & $\begin{array}{l}0.006 \\
(0.004)\end{array}$ \\
\hline $\begin{array}{l}\text { Actual working } \\
\text { experience }\end{array}$ & $\begin{array}{l}0.039 \\
(0.027)\end{array}$ & $\begin{array}{l}0.038 \\
(0.030)\end{array}$ & $\begin{array}{l}0.039 \\
(0.031)\end{array}$ & $\begin{array}{l}0.027 \\
(0.021)\end{array}$ & $\begin{array}{l}0.025 \\
(0.024)\end{array}$ & $\begin{array}{l}0.027 \\
(0.022)\end{array}$ \\
\hline White collar & $\begin{array}{l}0.016 \\
(0.010)\end{array}$ & $\begin{array}{l}0.018 \\
(0.013)\end{array}$ & $\begin{array}{l}0.016 \\
(0.013)\end{array}$ & $\begin{array}{l}-0.005 \\
(0.004)\end{array}$ & $\begin{array}{l}-0.004 \\
(0.004)\end{array}$ & $\begin{array}{l}-0.005 \\
(0.004)\end{array}$ \\
\hline Public jobs & $\begin{array}{l}-0.048 \\
(0.043)\end{array}$ & $\begin{array}{l}-0.043 \\
(0.031)\end{array}$ & $\begin{array}{l}-0.050 \\
(0.042)\end{array}$ & $\begin{array}{l}-0.036 \\
(0.027)\end{array}$ & $\begin{array}{l}-0.036 \\
(0.031)\end{array}$ & $\begin{array}{l}-0.039 \\
(0.032)\end{array}$ \\
\hline Extraversion & $\begin{array}{l}0.027 \\
(0.025)\end{array}$ & $\begin{array}{l}0.018 \\
(0.017)\end{array}$ & $\begin{array}{l}0.019 \\
(0.017)\end{array}$ & $\begin{array}{l}0.006 \\
(0.005)\end{array}$ & $\begin{array}{l}0.003 \\
(0.004)\end{array}$ & $\begin{array}{l}0.013 \\
(0.018)\end{array}$ \\
\hline
\end{tabular}




\begin{tabular}{lllllll} 
Agreeableness & 0.004 & 0.004 & 0.006 & 0.012 & 0.010 & 0.011 \\
& $(0.005)$ & $(0.004)$ & $(0.005)$ & $(0.015)$ & $(0.016)$ & $(0.009)$ \\
Conscientiously & 0.016 & 0.016 & 0.015 & 0.006 & 0.006 & 0.007 \\
& $(0.013)$ & $(0.015)$ & $(0.014)$ & $(0.007)$ & $(0.006)$ & $(0.006)$ \\
Emotional stability & -0.016 & -0.015 & -0.016 & -0.014 & -0.012 & -0.015 \\
& $(0.014)$ & $(0.013)$ & $(0.015)$ & $(0.015)$ & $(0.008)$ & $(0.010)$ \\
Openness & 0.018 & 0.021 & 0.018 & 0.013 & 0.010 & 0.014 \\
& $(0.015)$ & $(0.019)$ & $(0.016)$ & $(0.010)$ & $(0.009)$ & $(0.010)$ \\
$\mathrm{R}^{2}$ & 0.655 & 0.663 & 0.689 & 0.705 & 0.645 & 0.759 \\
Observations & 6,317 & 2,997 & 3,320 & 6,317 & 2,997 & 3,320 \\
\hline
\end{tabular}

Notes: Data set; 2008 Greek Behavioural Study. Standard errors are in parenthesis. *Significant at the $10 \%$ level.

** Significant at the $5 \%$ level. *** Significant at the $1 \%$ level. 
Total Sample

Men

Women

Men and Women

\begin{tabular}{|c|c|c|c|}
\hline Sexual activity & $0.032(0.013)^{* * *}$ & $0.038(0.014)^{* * *}$ & $0.030(0.011)^{* * *}$ \\
\hline Age & $0.300(0.058)^{* * *}$ & $0.310(0.044) * * *$ & $0.300(0.051)^{* * *}$ \\
\hline $\mathrm{Age}^{2}$ & $-0.000(0.000)^{* * *}$ & $-0.000(0.000) * * *$ & $-0.000(0.000) * * *$ \\
\hline Men & $0.078(0.021)^{* * *}$ & - & - \\
\hline Homosexuality & $-0.087(0.030) * * *$ & $-0.085(0.035)^{* * *}$ & $-0.092(0.041) * * *$ \\
\hline Married & $0.106(0.040)^{* * *}$ & $0.105(0.040)^{* * *}$ & $0.100(0.040)^{* * *}$ \\
\hline Migrants & $-0.117(0.022) * * *$ & $-0.110(0.024)^{* * *}$ & $-0.186(0.025) * * *$ \\
\hline Disability status & $-0.183(0.050) * * *$ & $-0.160(0.053)^{* * *}$ & $-0.203(0.065) * * *$ \\
\hline Daily medication & $-0.090(0.037) * * *$ & $-0.084(0.045)^{* *}$ & $-0.125(0.054) * * *$ \\
\hline Diabetes & $-0.094(0.047)^{*}$ & $-0.090(0.047)^{*}$ & $-0.116(0.061)^{*}$ \\
\hline Heart diseases & $-0.087(0.045)^{* *}$ & $-0.078(0.040)^{*}$ & $-0.120(0.064)^{* *}$ \\
\hline Arthritis & $-0.043(0.025)^{*}$ & $-0.040(0.022) *$ & $-0.044(0.025) *$ \\
\hline Cancer & $-0.097(0.048) * *$ & $-0.095(0.049) * *$ & $-0.096(0.048) * *$ \\
\hline $\begin{array}{l}\text { Psychiatric / psychological } \\
\text { symptoms }\end{array}$ & $-0.043(0.022)^{*}$ & $-0.043(0.024) *$ & $-0.045(0.024)^{* *}$ \\
\hline $\begin{array}{l}\text { University or technical } \\
\text { school degree }\end{array}$ & $0.350(0.100)^{* * *}$ & $0.378(0.086)^{* * *}$ & $0.345(0.087) * * *$ \\
\hline Actual working experience & $0.364(0.050)^{* * *}$ & $0.378(0.086)^{* * *}$ & $0.343(0.087)^{* * *}$ \\
\hline Actual working experience ${ }^{2}$ & $-0.000(0.000) * * *$ & $-0.000(0.000)^{* * *}$ & $-0.000(0.000)^{* * *}$ \\
\hline White collar & $0.218(0.061)^{* * *}$ & $0.221(0.062)^{* * *}$ & $0.215(0.057)^{* * *}$ \\
\hline Public jobs & $0.254(0.103)^{* * *}$ & $0.268(0.119)^{* * *}$ & $0.245(0.105)^{* * *}$ \\
\hline Extraversion & $0.012(0.004)^{* * *}$ & $0.018(0.006)^{* * *}$ & $0.009(0.005)^{* *}$ \\
\hline Agreeableness & $0.010(0.010)$ & $0.012(0.009)$ & $0.013(0.008)$ \\
\hline Conscientiously & $0.005(0.010)$ & $0.005(0.009)$ & $0.008(0.007)$ \\
\hline Emotional stability & $0.010(0.009)$ & $0.010(0.009)$ & 0.009 (0.007) \\
\hline Openness & $0.007(0.006)$ & $0.008(0.007)$ & $0.010(0.008)$ \\
\hline $\begin{array}{l}\text { Sargan-Hansen over- } \\
\text { identification test }\end{array}$ & $0.362(0.260)$ & $0.219(0.195)$ & $0.424(0.306)$ \\
\hline F-statistic on instrument & $0.486(0.340)$ & $0.404(0.315)$ & $0.447(0.430)$ \\
\hline $\mathrm{R}^{2}$ & 0.842 & 0.847 & 0.829 \\
\hline$\delta$ coefficient & $0.016(0.013)$ & $0.022(0.017)$ & $0.015(0.013)$ \\
\hline Observations & 4,932 & 2,405 & 2,527 \\
\hline
\end{tabular}

Notes: Data set; 2008 Greek Behavioural Study. Standard errors are in parenthesis. *Significant at the 10\% level. ** Significant at the $5 \%$ level. *** Significant at the $1 \%$ level. 

Panel II Panel III

Total Sample Men Women

Men and Women

Sexual activity

- 18-25 years of age

$-18-25$ years of age $x$ Sexual activity

-26-50 years of age

-26-50 years of age $x$ Sexual activity

$-52-65$ years of age

$-52-65$ years of age $x$ Sexual activity

Men

Homosexuality

Homosexuality x Sexual activity

Married

Married x Sexual activity

Migrants

Migrants x Sexual activity

Disability status

Disability status x Sexual activity

Daily medication

Daily medication x Sexual activity

Diabetes

Diabetes x Sexual activity

Heart diseases

Heart diseases x Sexual activity

Arthritis

Arthritis x Sexual activity

Cancer

Cancer $\mathrm{x}$ Sexual activity

Psychiatric / psychological symptoms

Psychiatric / psychological symptoms

$\mathrm{x}$ Sexual activity

University or technical school degree

University or technical school degree

$\mathrm{x}$ Sexual activity

Actual working experience

Actual working experience $\mathrm{x}$ Sexual activity

Actual working experience ${ }^{2}$

White collar

White collar x Sexual activity

Public jobs

Public jobs x Sexual activity

Extraversion

Extraversion $\mathrm{x}$ Sexual activity

Agreeableness

\begin{tabular}{|c|c|c|}
\hline $0.032(0.013)^{* * *}$ & $0.038(0.014)^{* * *}$ & $0.030(0.011)^{* * *}$ \\
\hline $0.217(0.045)^{* * *}$ & $0.225(0.043)^{*}$ & $0.118(0.035)^{*}$ \\
\hline $039(0.025)$ & $0.042(0.036)$ & $0.039(0.026)$ \\
\hline $0.324(0.036)^{* * *}$ & $0.331(0.016)^{* * *}$ & $0.321(0.098) * * *$ \\
\hline $0.054(0.029) *$ & $0.054(0.028) *$ & $0.049(0.026)^{*}$ \\
\hline $0.337(0.109)^{* * *}$ & $0.340(0.097)^{* * *}$ & $0.330(0.105)^{* * *}$ \\
\hline $0.028(0.020)$ & $0.028(0.019)$ & $0.029(0.024)$ \\
\hline $0.078(0.021$ & - & \\
\hline$-0.087(0.03$ & $-0.085(0.035) * * *$ & $-0.092(0.041)^{* * *}$ \\
\hline $0.007(0.006)$ & 0.009 (0.010) & $0.011(0.008)$ \\
\hline $0.106(0.04$ & $0.105(0.0$ & $40) * * *$ \\
\hline $0.076(0.01$ & $0.079(0.0$ & 0.074 \\
\hline$-0.117(0.0$ & $-0.110(0.0$ & $.025) * * *$ \\
\hline $0.016(0.010)$ & $0.010(0.009)$ & 0.018 \\
\hline$-0.183(0.0$ & $-0.163(0$ & -0.20 \\
\hline $0.012(0.00$ & $0.014(0.0$ & 0.018 \\
\hline-0.09 & -0.084 & $54) * * *$ \\
\hline 0.010( & $0.011(0.00$ & $007)^{* *}$ \\
\hline-0.09 & -0.09 & -0.116 \\
\hline & 0.015 & 0.013 \\
\hline-0.0 & -0.0 & -0.12 \\
\hline 0.013 & 0.012 & 0.013 \\
\hline$-0.043(0$. & $-0.040(0$ & -0.04 \\
\hline & & \\
\hline-0.0 & -0.0 & $8)^{* *}$ \\
\hline $0.010(0$. & 0.014 & 0.015 \\
\hline-0.0 & -0.04 & $-0 . C$ \\
\hline 0.005 & $0.00 €$ & 0.00 \\
\hline & & \\
\hline $0.107(0.097)$ & $0.098(0.065)$ & $0.119(0.097)$ \\
\hline 0.364 & 0.07 & 0.343 \\
\hline $0.053(0.017)^{* * *}$ & $0.065(0.017)^{* * *}$ & $0.050(0.027)^{* *}$ \\
\hline$-0.000(0.000)^{* * *}$ & $-0.000(0.000)^{* * *}$ & $.000)^{* * *}$ \\
\hline $0.218(0.061)^{* * *}$ & $0.221(0.062)^{* * *}$ & $0.215(0.057)^{* * *}$ \\
\hline $0.016(0.015)$ & $0.026(0.020)$ & $0.014(0.010)$ \\
\hline $0.254(0.103)^{* * *}$ & $0.268(0.119) * * *$ & $0.245(0.105)^{* * *}$ \\
\hline $0.015(0.014)$ & $0.016(0.014)$ & $0.014(0.010)$ \\
\hline $0.012(0.004)^{* * *}$ & $0.018(0.006)^{* * *}$ & $0.009(0.005)^{* *}$ \\
\hline$* * *$ & $.010) * * *$ & $0.020(0.010)^{* * *}$ \\
\hline $0.010(0.010)$ & $0.012(0.009)$ & $0.013(0.008)$ \\
\hline
\end{tabular}




\begin{tabular}{llll} 
Agreeableness x Sexual activity & $0.013(0.012)$ & $0.009(0.009)$ & $0.013(0.011)$ \\
Conscientiously & $0.005(0.010)$ & $0.005(0.009)$ & $0.008(0.007)$ \\
Conscientiously x Sexual activity & $0.010(0.011)$ & $0.007(0.006)$ & $0.011(0.009)$ \\
Emotional stability & $0.010(0.009)$ & $0.010(0.009)$ & $0.009(0.007)$ \\
Emotional stability x Sexual activity & $0.010(0.010)$ & $0.006(0.008)$ & $0.012(0.011)$ \\
Openness & $0.007(0.006)$ & $0.008(0.007)$ & $0.010(0.008)$ \\
Openness x Sexual activity & $0.015(0.008)^{*}$ & $0.017(0.005)^{* * *}$ & $0.015(0.009)^{*}$ \\
Sargan-Hansen over-identification test & $0.362(0.260)$ & $0.219(0.195)$ & $0.424(0.306)$ \\
F-statistic on instrument & $0.486(0.340)$ & $0.404(0.315)$ & $0.447(0.430)$ \\
$\mathrm{R}^{2}$ & 0.842 & 0.847 & 0.829 \\
$\delta$ coefficient & $0.016(0.013)$ & $0.022(0.017)$ & $0.015(0.013)$ \\
Observations & 4,932 & 2,405 & 2,527 \\
\hline
\end{tabular}

Notes: Data set; 2008 Greek Behavioural Study. Standard errors are in parenthesis. *Significant at the 10\% level.

** Significant at the $5 \%$ level. *** Significant at the $1 \%$ level. 


\begin{tabular}{lcc}
\multicolumn{1}{c}{ Panel I } & Panel II & \multicolumn{1}{c}{ Panel III } \\
$\begin{array}{l}\text { Total Sample } \\
\text { Men and Women }\end{array}$ & Men & Women \\
\hline
\end{tabular}

- No sexual activity

- Sexual activity: once or twice a year

- Sexual activity: once a month

- Sexual activity: two to three times a month

- Sexual activity: two to three times a week

- Sexual activity: more than four times a week

Age

Age $x$ No sex

$\mathrm{Age}^{2}$

Men

Men x No sex

Homosexuality

Homosexuality x No sex

Married

Married x No sex

Migrants

Migrants x No sex

Disability status

Disability status $\mathrm{x}$ No sex

Daily medication

Daily medication x No sex

Diabetes

Diabetes x No sex

Heart diseases

Heart diseases $\mathrm{x}$ No sex

Arthritis

Arthritis x No sex

Cancer

Cancer x No sex

Psychiatric / psychological symptoms

Psychiatric / psychological symptoms $\mathrm{x}$

No sex

University or technical school degree

University or technical school degree

$\mathrm{x}$ No sex

Actual working experience

Actual working experience $\mathrm{x}$ No sex

Actual working experience ${ }^{2}$

White collar

White collar x No sex

Public

Public jobs $x$ No sex

Extraversion

\begin{tabular}{|c|c|c|}
\hline$-0.032(0.013) * * *$ & $-0.038(0.014) * * *$ & $-0.030(0.011)^{* * *}$ \\
\hline$-0.016(0.006) * * *$ & $-0.042(0.020) * * *$ & $-0.007(0.004)^{*}$ \\
\hline $0.040(0.020)^{* * *}$ & $0.045(0.015)^{* * *}$ & $0.036(0.015)^{* * *}$ \\
\hline $0.043(0.020)^{* * *}$ & $0.049(0.021)^{* * *}$ & $0.040(0.012)^{* * *}$ \\
\hline $0.045(0.018)^{* * *}$ & $0.045(0.020)^{* * *}$ & $0.042(0.020)^{* * *}$ \\
\hline $0.047(0.020)^{* * *}$ & $0.047(0.021)^{* * *}$ & $0.044(0.014)^{* * *}$ \\
\hline $0.300(0.058) * * *$ & $0.310(0.044)^{* * *}$ & $0.300(0.051)^{* * *}$ \\
\hline$-0.019(0.013)$ & $-0.018(0.012)$ & $-0.019(0.014)$ \\
\hline$-0.000(0.000) * * *$ & $-0.000(0.000) * * *$ & $-0.000(0.000) * * *$ \\
\hline $0.078(0.021)^{* * *}$ & - & - \\
\hline$-0.010(0.003)^{*}$ & & \\
\hline$-0.087(0.030) * * *$ & $-0.085(0.035) * * *$ & $-0.092(0.041)^{* * *}$ \\
\hline$-0.014(0.012)$ & $-0.014(0.020)$ & $-0.011(0.015)$ \\
\hline $0.106(0.040) * * *$ & $0.105(0.040)^{* * *}$ & $0.100(0.040)^{* * *}$ \\
\hline$-0.012(0.010)$ & $-0.013(0.007)^{* *}$ & $-0.012(0.011)$ \\
\hline$-0.117(0.022)^{* * *}$ & $-0.110(0.024) * * *$ & $-0.186(0.025) * * *$ \\
\hline$-0.011(0.010)$ & $-0.013(0.016)$ & $-0.009(0.011)$ \\
\hline$-0.183(0.050) * * *$ & $-0.163(0.053) * * *$ & $-0.203(0.068) * * *$ \\
\hline$-0.012(0.012)$ & $-0.015(0.017)$ & $-0.009(0.011)$ \\
\hline$-0.090(0.037) * * *$ & $-0.084(0.045)^{* *}$ & $-0.125(0.054) * * *$ \\
\hline$-0.012(0.012)$ & $-0.012(0.010)$ & $-0.011(0.010)$ \\
\hline$-0.094(0.047)^{*}$ & $-0.090(0.047) *$ & -0.116 \\
\hline$-0.009(0$. & $-0.013(0.011)$ & $-0.014(0.012)$ \\
\hline$-0.087(0.045)^{* *}$ & $-0.078(0.040) *$ & $-0.120(0.064)^{* *}$ \\
\hline$-0.010(0.007)$ & $-0.010(0.010)$ & $-0.012(0.010)$ \\
\hline$-0.043(0.025)^{*}$ & $-0.040(0.022)^{*}$ & $-0.044(0.025) *$ \\
\hline$-0.010(0.021)$ & $-0.010(0.018)$ & $-0.011(0.01$ \\
\hline$-0.097(0.048)^{* *}$ & $-0.095(0.049)^{* *}$ & $-0.096(0.048) * *$ \\
\hline$-0.013(0.010)$ & $-0.013(0.011)$ & $-0.012(0.011)$ \\
\hline$-0.043(0.022)^{*}$ & $-0.043(0.024) *$ & $-0.045(0.024)^{* *}$ \\
\hline$-0.015(0.011)$ & $-0.015(0.010)$ & $-0.014(0.012)$ \\
\hline $0.350(0.100)^{* * *}$ & $0.378(0.086)^{* * *}$ & $0.345(0.087)^{*}$ \\
\hline$-0.027(0.020)$ & $-0.021(0.030)$ & $-0.028(0.031)$ \\
\hline $0.364(0.050) * * *$ & $0.378(0.086)^{* * *}$ & $0.343(0.087)^{* * *}$ \\
\hline $0.006(0.010)$ & $0.006(0.006)$ & $0.006(0.007)$ \\
\hline$-0.000(0.000) * * *$ & $-0.000(0.000) * * *$ & $-0.000(0.000) * * *$ \\
\hline $0.218(0.061)^{* * *}$ & $0.221(0.062)^{* * *}$ & $0.215(0.057)^{* * *}$ \\
\hline$-0.054(0.042)$ & $-0.052(0.039)$ & $-0.041(0.032)$ \\
\hline $0.254(0.103) * * *$ & $0.268(0.119)^{* * *}$ & $0.245(0.105)^{* * *}$ \\
\hline-0.023 & $-0.027(0.020)$ & $-0.028(0.023)$ \\
\hline $0.012(0.004)^{* * *}$ & $0.018(0.006)^{* * *}$ & $0.009(0.005)^{* *}$ \\
\hline
\end{tabular}




\begin{tabular}{llll} 
Extraversion x No sex & $0.010(0.006)$ & $0.016(0.020)$ & $0.013(0.012)$ \\
Agreeableness & $0.010(0.010)$ & $0.012(0.009)$ & $0.013(0.008)$ \\
Agreeableness x No sex & $0.008(0.007)$ & $0.005(0.005)$ & $0.007(0.006)$ \\
Conscientiously & $0.005(0.010)$ & $0.005(0.009)$ & $0.008(0.007)$ \\
Conscientiously x No sex & $0.012(0.013)$ & $0.010(0.007)$ & $0.013(0.013)$ \\
Emotional stability & $0.010(0.009)$ & $0.010(0.009)$ & $0.009(0.007)$ \\
Emotional stability x No sex & $0.012(0.012)$ & $0.004(0.004)$ & $0.005(0.006)$ \\
Openness & $0.007(0.006)$ & $0.008(0.007)$ & $0.010(0.008)$ \\
Openness x No sex & $0.005(0.004)$ & $0.010(0.008)$ & $0.012(0.010)$ \\
Sargan-Hansen over-identification test & $0.362(0.260)$ & $0.219(0.195)$ & $0.424(0.306)$ \\
F-statistic on instrument & $0.486(0.340)$ & $0.404(0.315)$ & $0.447(0.430)$ \\
$R^{2}$ & 0.876 & 0.856 & 0.834 \\
$\delta$ coefficient & $0.016(0.011)$ & $0.022(0.020)$ & $0.013(0.012)$ \\
Observations & 4,932 & 2,405 & 2,527 \\
\hline
\end{tabular}

Notes: Data set; 2008 Greek Behavioural Study. Standard errors are in parenthesis. *Significant at the $10 \%$ level. ** Significant at the $5 \%$ level. *** Significant at the 1\% level. 


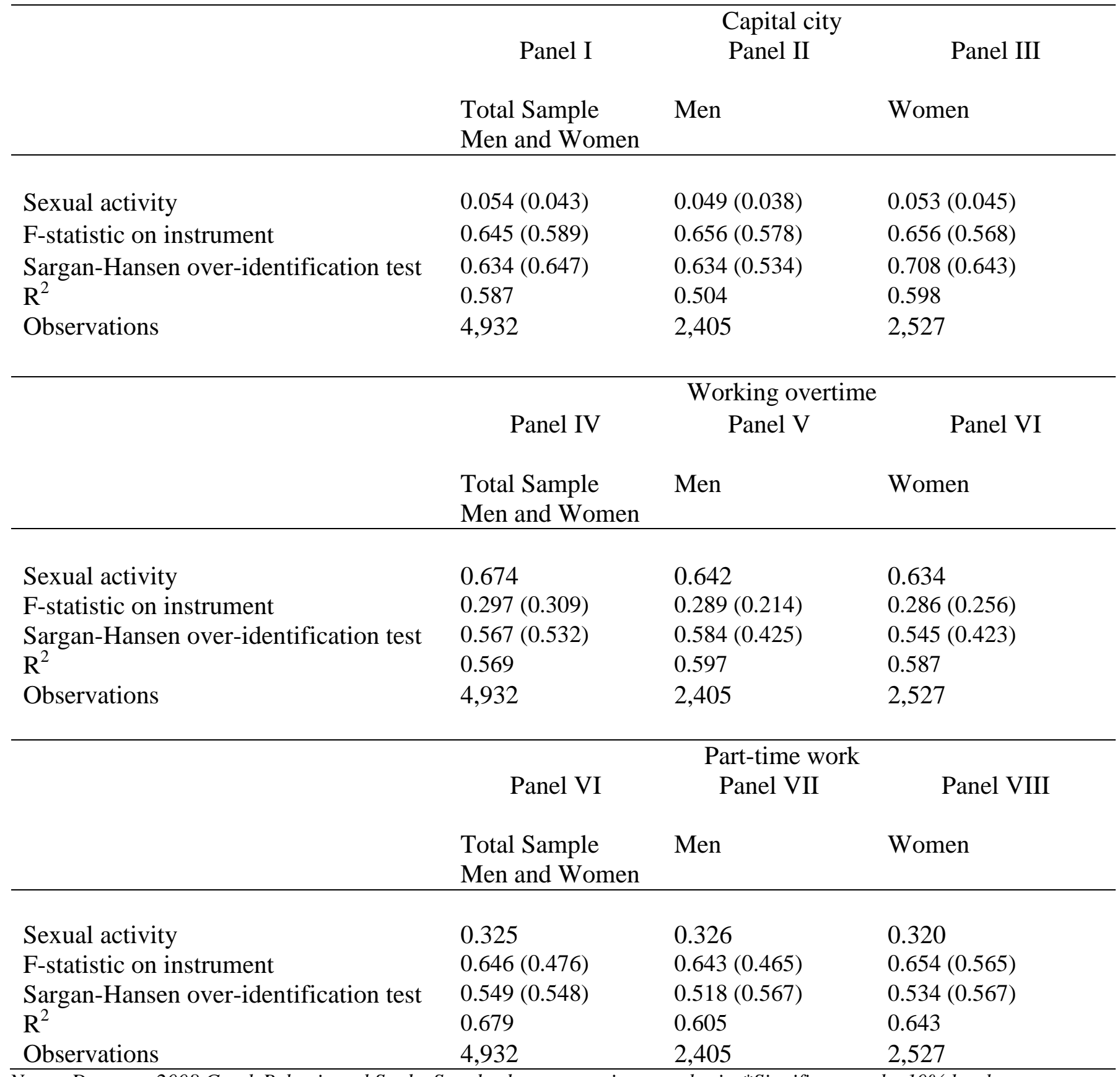

Notes: Data set; 2008 Greek Behavioural Study. Standard errors are in parenthesis. *Significant at the $10 \%$ level.

** Significant at the 5\% level. *** Significant at the 1\% level. All specifications include the full set of controls in Table 5. 
Table 9. Oaxaca-Blinder Decomposition outcomes per group

Panel I $\quad$ Panel II $\quad$ Panel III

Panel IV Panel V

$\begin{array}{llllll}\text { Groups } & \begin{array}{l}\text { Raw } \\ \text { Differential }\end{array} & \begin{array}{l}\text { Explained } \\ \text { Differential }\end{array} & \begin{array}{l}\text { Unexplained } \\ \text { Differential }\end{array} & \begin{array}{l}\text { Residuals } \\ \text { Effects }\end{array} & \begin{array}{l}\text { Explained } \\ \text { Differential } \\ \text { due to sexual } \\ \text { activity }\end{array}\end{array}$

\begin{tabular}{|c|c|c|c|c|c|}
\hline $\begin{array}{l}\text { Men - } \\
\text { Women }\end{array}$ & $\begin{array}{l}0.442 \\
(0.038) * * *\end{array}$ & $\begin{array}{l}0.919 \\
(0.018) * * *\end{array}$ & $\begin{array}{l}0.077 \\
(0.006)^{* * *}\end{array}$ & $\begin{array}{l}0.003 \\
(0.002)\end{array}$ & $\begin{array}{l}0.043 \\
(0.026)\end{array}$ \\
\hline Natives - Immigrants & $\begin{array}{l}0.703 \\
(0.109) * * *\end{array}$ & $\begin{array}{l}0.870 \\
(0.024) * * *\end{array}$ & $\begin{array}{l}0.118 \\
(0.010)^{* * *}\end{array}$ & $\begin{array}{l}0.012 \\
(0.010)\end{array}$ & $\begin{array}{l}0.027 \\
(0.021)\end{array}$ \\
\hline $\begin{array}{l}\text { Heterosexual men - Gay } \\
\text { men }\end{array}$ & $\begin{array}{l}0.624 \\
(0.092) * * *\end{array}$ & $\begin{array}{l}0.909 \\
(0.038) * * *\end{array}$ & $\begin{array}{l}0.084 \\
(0.003)^{* * *}\end{array}$ & $\begin{array}{l}0.006 \\
(0.007)\end{array}$ & $\begin{array}{l}0.031 \\
(0.028)\end{array}$ \\
\hline $\begin{array}{l}\text { Heterosexual women - } \\
\text { Lesbian women }\end{array}$ & $\begin{array}{l}0.639 \\
(0.035) * * *\end{array}$ & $\begin{array}{l}0.889 \\
(0.025)^{* * *}\end{array}$ & $\begin{array}{l}0.093 \\
(0.009) * * *\end{array}$ & $\begin{array}{l}0.017 \\
(0.094)\end{array}$ & $\begin{array}{l}0.029 \\
(0.025)\end{array}$ \\
\hline $\begin{array}{l}\text { Healthy employees - } \\
\text { Disabled employees }\end{array}$ & $\begin{array}{l}0.679 \\
(0.008) * * *\end{array}$ & $\begin{array}{l}0.840 \\
(0.020)^{* * *}\end{array}$ & $\begin{array}{l}0.158 \\
(0.016)^{* * *}\end{array}$ & $\begin{array}{l}0.010 \\
(0.075)\end{array}$ & $\begin{array}{l}0.011 \\
(0.010)\end{array}$ \\
\hline
\end{tabular}

Notes: Data set; 2008 Greek Behavioural Study. Standard errors are in parenthesis. ${ }^{* * *}$ Significant at the 1\% level. All specifications include the full set of controls in Table 5. 
Total Sample

Men

Women

Men and Women

\begin{tabular}{|c|c|c|c|}
\hline Sexual activity & $0.032(0.010)^{* * *}$ & $0.038(0.015)^{* * *}$ & $0.030(0.011)^{* * *}$ \\
\hline Age & $0.300(0.058)^{* * *}$ & $0.310(0.038)^{* * *}$ & $0.300(0.051)^{* * *}$ \\
\hline Age $^{2}$ & $-0.000(0.000)^{* * *}$ & $-0.000(0.000)^{* * *}$ & $-0.000(0.000)^{* * *}$ \\
\hline Men & $0.078(0.021)^{* * *}$ & - & - \\
\hline Homosexuality & $-0.087(0.027) * * *$ & $-0.085(0.035) * * *$ & $-0.092(0.041)^{* * *}$ \\
\hline Married & $0.106(0.037)^{* * *}$ & $0.105(0.040) * * *$ & $0.100(0.040)^{* * *}$ \\
\hline Migrants & $-0.117(0.022) * * *$ & $-0.110(0.023) * * *$ & $-0.184(0.025) * * *$ \\
\hline Disability status & $-0.183(0.050)^{* * *}$ & $-0.160(0.053) * * *$ & $-0.203(0.063) * * *$ \\
\hline Daily medication & $-0.090(0.037) * * *$ & $-0.084(0.045)^{* *}$ & $-0.125(0.053) * * *$ \\
\hline Diabetes & $-0.093(0.046)^{*}$ & $-0.090(0.046)^{*}$ & $-0.116(0.059)^{*}$ \\
\hline Heart diseases & $-0.084(0.045) * *$ & $-0.078(0.040)^{*}$ & $-0.120(0.063)^{* *}$ \\
\hline Arthritis & $-0.043(0.025)^{*}$ & $-0.040(0.022)^{*}$ & $-0.044(0.025)^{*}$ \\
\hline Cancer & $-0.097(0.046)^{* *}$ & $-0.095(0.046) * *$ & $-0.096(0.048)^{* *}$ \\
\hline $\begin{array}{l}\text { Psychiatric / psychological } \\
\text { symptoms }\end{array}$ & $-0.043(0.020)^{*}$ & $-0.043(0.024)^{*}$ & $-0.045(0.024)^{* *}$ \\
\hline $\begin{array}{l}\text { University or technical } \\
\text { school degree }\end{array}$ & $0.350(0.100)^{* * *}$ & $0.378(0.086)^{* * *}$ & $0.345(0.085)^{* * *}$ \\
\hline Actual working experience & $0.365(0.050)^{* * *}$ & $0.378(0.086)^{* * *}$ & $0.343(0.087) * * *$ \\
\hline Actual working experience ${ }^{2}$ & $-0.000(0.000) * * *$ & $-0.000(0.000) * * *$ & $-0.000(0.000) * * *$ \\
\hline White collar & $0.218(0.057)^{* * *}$ & $0.221(0.062)^{* * *}$ & $0.210(0.056)^{* * *}$ \\
\hline Extraversion & $0.012(0.004)^{* * *}$ & $0.017(0.006)^{* * *}$ & $0.009(0.005)^{* *}$ \\
\hline Agreeableness & $0.010(0.009)$ & $0.012(0.009)$ & $0.012(0.008)$ \\
\hline Conscientiously & $0.005(0.010)$ & $0.005(0.009)$ & 0.007 (0.007) \\
\hline Emotional stability & $0.010(0.009)$ & $0.010(0.009)$ & $0.009(0.007)$ \\
\hline Openness & $0.007(0.006)$ & $0.008(0.007)$ & $0.010(0.008)$ \\
\hline $\begin{array}{l}\text { Sargan-Hansen over- } \\
\text { identification test }\end{array}$ & $0.360(0.260)$ & $0.219(0.195)$ & $0.424(0.306)$ \\
\hline F-statistic on instrument & $0.486(0.340)$ & $0.402(0.325)$ & $0.447(0.407)$ \\
\hline $\mathrm{R}^{2}$ & 0.839 & 0.853 & 0.835 \\
\hline Inverse Mills Ratio & $1.360(0.911)$ & $1.253(0.947)$ & $1.354(0.901)$ \\
\hline$\delta$ coefficient & $0.016(0.013)$ & $0.022(0.017)$ & $0.015(0.012)$ \\
\hline Observations & 4,932 & 2,405 & 2,527 \\
\hline
\end{tabular}

Notes: Data set; 2008 Greek Behavioural Study. Standard errors are in parenthesis. *Significant at the $10 \%$ level. ** Significant at the $5 \%$ level. *** Significant at the $1 \%$ level. 
SA Sexual activity:

0 : no; 1 : once or twice a year; 2 : once a month; 3 : two to three times a month; 4 : weekly;

HW $\quad$ 5: two to three times a week; 6: more

AGE Years of age

AGES Years of age squared

GEN 1 if individual is male; 0 otherwise

HOMO 1 if individual is homosexual (gay man or lesbian woman); 0 otherwise

MARR 1 if individual is married; 0 otherwise

IMM 1 if individual is an immigrant; 0 otherwise

DS $\quad 1$ if individual is limited in kind or amount of work, has a mobility limitation, or has a personal care limitation; 0 otherwise

DM $\quad 1$ if the respondent takes daily medications; 0 otherwise

DIA 1 if the respondent has ever been told by a doctor's diagnosis that she/he had diabetes; 0 otherwise

HEA 1 if the respondent has ever been told by a doctor that she/he had a heart attack, coronary heart disease, angina, congestive heart failure, or other heart problems; 0 otherwise

ART 1 if the respondent has ever been told by a doctor that she/he had arthritis or rheumatism;

CAN 1 if the respondent has ever been told by a doctor that she/he had cancer; 0 otherwise

PSY 1 if the respondent has ever been told by a doctor that she/he had otherwise Psychiatric / psychological symptoms ; 0

UNIV 1 if individual has university or a technical school diploma; 0 otherwise

EMPL 1 if individual is employed; 0 otherwise

LAFOR 1 if individual is in the labour force (employed and unemployed); 0 otherwise

EXPER Years of actual working experience

EXPERS Years of actual working experience squared

WHITE 1 if individual's occupation is among managerial or professional specialties, or the individual works in a technical, sales, or administrative support position; 0 otherwise

PUBL 1 if individual is employed in the public sector; 0 if individual is employed in the private sector (PRIV; reference group)

G Believe in God:1 if individual believes in God; 0 otherwise

RS Attendance of religious services:

1 if individual attends religious services at least 2 times per month; 0 otherwise

EXT 1 if individual is characterised by extraversion (Big Five Personality Traits index); 0 otherwise

AGR 1 if individual is characterised by agreeableness (Big Five Personality Traits index); 0 otherwise

CON 1 if individual is characterised by conscientiousness (Big Five Personality Traits 
index); 0 otherwise

NEU 1 if individual is characterised by emotional stability (Big Five Personality Traits index); 0 otherwise

OPE $\quad 1$ if individual is characterised by openness (Big Five Personality Traits index); 0 otherwise

WCS 1 if individual is working in the capital city; 0 otherwise

WOT 1 if individual is working over-time; 0 otherwise

WPT 1 if individual is working part-time; 0 otherwise

NINC Natural logarithm of non-labour income (monthly)

MUNIV 1 if individual's mother has university or a technical school diploma; 0 otherwise

FUNIV 1 if individual's father has university or a technical school diploma; 0 otherwise 
Appendix B. Sub-correlation matrix (31x2)

\begin{tabular}{lll}
\hline & 1. Sexual activity & 2. Wage (hourly) \\
1. Sexual activity & 1.000 & $0.774^{* * *}$ \\
2. Wage (hourly) & $0.774^{* * *}$ & 1.000 \\
3. Age & $-0.769^{* * *}$ & $0.758^{* * *}$ \\
4. Men & $0.845^{* * *}$ & $0.865^{* * *}$ \\
5. Homosexuality & 0.535 & -0.705 \\
6. Married & $0.864^{* * *}$ & $0.678^{* * *}$ \\
7. Migrants & $-0.648^{*}$ & $-0.856^{* * *}$ \\
8. University or technical school degree & 0.658 & $0.905^{* * *}$ \\
9. Actual working experience & 0.483 & $0.839^{* * *}$ \\
10. White collar employee & 0.574 & $0.749^{* * *}$ \\
11. Public employee & 0.648 & $0.739^{* * *}$ \\
12. Disability status & $-0.875^{* * *}$ & $-0.807^{* * *}$ \\
13. Daily medication & $-0.756^{* * *}$ & $-0.764^{* * *}$ \\
14. Diabetes & $-0.634^{*}$ & $-0.667^{* *}$ \\
15. Heart diseases & $-0.865^{* * *}$ & $-0.590^{*}$ \\
16. Arthritis & $-0.658^{* * *}$ & $-0.560^{*}$ \\
17. Cancer & $-0.846^{* * *}$ & $-0.608^{* * *}$ \\
18. Psychiatric / psychological symptoms & $-0.637^{* *}$ & $-0.635^{*}$ \\
19. Believe in God & $-0.878^{* * *}$ & 0.361 \\
20. Religious services attendance & $-0.846^{* * *}$ & 0.294 \\
21. Extraversion & $0.765^{* *}$ & $0.687^{* *}$ \\
22. Agreeableness & 0.456 & 0.536 \\
23. Conscientiousness & 0.665 & 0.434 \\
24. Emotional stability & 0.637 & 0.565 \\
25. Openness & 0.653 & 0.535 \\
26. Working in the capital city & 0.369 & $0.776^{* *}$ \\
27. Working over-time & 0.456 & $0.845^{* * *}$ \\
28. Working part-time & 0.535 & $-0.765^{* * *}$ \\
29. Non-labour income (monthly) & 0.524 & 0.374 \\
30. Mother's university or technical school degree & 0.389 & 0.340 \\
31. Father's university or technical school degree & 0.305 & 0.418 \\
\hline
\end{tabular}

Notes: Data set; 2008 Greek Behavioural Study. Standard errors are in parenthesis. We use Spearman correlation coefficient to estimate correlations for both scales ordinal. We use Biserial correlation coefficient to estimate correlations between ordinal quantitative variables. We use Rank-Biserial correlation coefficient to estimate correlations between ordinal and nominal variables. *Significant at the 10\% level. ** Significant at the $5 \%$ level. ${ }^{* * *}$ Significant at the $1 \%$ level. 